UNIVERSIDADE ESTADUAL PAULISTA “JULIO DE MESQUITA FILHO” FACULDADE DE CIÊNCIAS AGRÁRIAS E VETERINÁRIAS CÂMPUS DE JABOTICABAL

\title{
ANÁLISE HISTÓRICO-CULTURAL, PAISAGÍSTICA E QUALI-QUANTITATIVA DOS ELEMENTOS ARQUITETÔNICOS DA PRAÇA SETE DE SETEMBRO, RIBEIRÃO PRETO, SP.
}

Renata Gimenes

Orientadora: Profa. Dra. Kathia Fernandes Lopes Pivetta

Dissertação apresentada à Faculdade de Ciências Agrárias e Veterinárias - Unesp, Campus de Jaboticabal, como parte das exigências para a obtenção do título de Mestre em Agronomia (Produção Vegetal).

JABOTICABAL - SÃO PAULO - BRASIL

Março - 2010 


\section{DADOS CURRICULARES DA AUTORA}

RENATA GIMENES - nascida em 12 de maio de 1980 em Ribeirão Preto - SP, graduada em Engenharia Agronômica pela Universidade Estadual Paulista Júlio de Mesquita Filho (2008). Foi bolsista de iniciação científica no período de 2005 a 2007. Atualmente é aluna de Mestrado do curso de Pós-Graduação em Agronomia Produção Vegetal pela FCAV/UNESP Jaboticabal. Atua na área de Agronomia, com ênfase em Floricultura e Paisagismo, trabalhando principalmente com germinação de sementes de palmeiras, micropropagação de orquídeas, paisagismo e planejamento de praças. 
Dedico este trabalho àqueles que foram fundamentais para a minha formação pessoal

$$
\begin{array}{r}
\text { Aos meus avós } \\
\text { Vicente Gimenes (in memorian) } \\
\text { Ilda Delefrate Gimenes (in memorian) }
\end{array}
$$

Aos meus pais

Vicente Gimenes Filho e Teresinha Pereira da Silva À minha tia Célia Regina Gimenes Gonçalves 


\section{AGRADECIMENTOS}

Agradeço à Deus pelo milagre da vida e por sua constante presença, mostrandome o caminho certo a percorrer em todos os momentos.

À Profa. Kátia Fernandes Lopes Pivetta pela orientação, incentivo e contribuição com a minha formação e vida acadêmica.

Aos meus queridos amigos Diego da Silva Siqueira, Gisele Sales Batista, Gustavo da Nobrega Romani e Vanessa Cury Galatti, pelos dias agradáveis, além das colaborações nas horas de dificuldades.

À minha irmã Lis que me presenteou com um sobrinho, Arthur, tornando a minha vida mais colorida.

À Prefeitura Municipal de Ribeirão Preto, principalmente à Regina Maria Alves Carneiro e Perci Guzzo.

Ao Arquivo Público e Histórico de Ribeirão Preto, em especial à Tânia Cristina Registro, pessoa muito solícita ao meu trabalho.

Ao João Rossato e Elza Rossato por dispor de seus materiais fotográficos, contribuindo com meu trabalho.

Agradeço ao meu marido Anderson pelo apoio, companheirismo e credibilidade que deposita em mim. 
SUMÁRIO

Páginas

LISTA DE FIGURAS................................................................................ vii

LISTA DE ANEXOS

1. INTRODUÇÃO.

2. REVISÃO DE LITERATURA ………………….................................. 3

2.1. Paisagismo . ........................................................................ 3

2.2. Espaços Livres............................................................................. 4

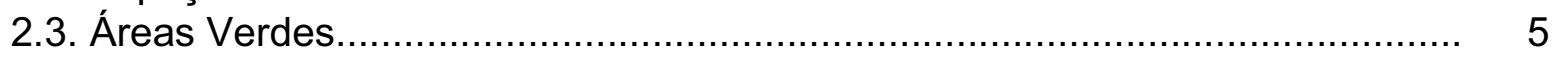

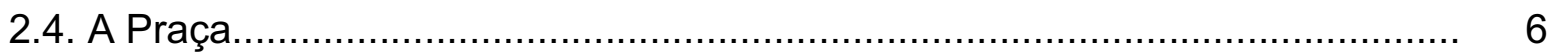

2.5. A evolução das praças no Brasil.......................................................... 9

2.6. Benefícios das praças................................................................... 12

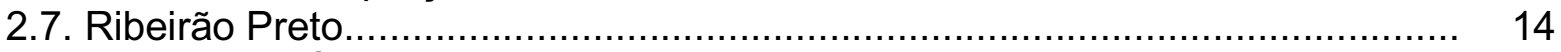

3. MATERIAL E MÉTODOS............................................................................ 15

3.1. Levantamento histórico e documental da Praça Sete de Setembro................. 15

3.2. Levantamento quali-quantitativo dos elementos arquitetônicos...................... 15

3.3. Análise quali-quantitativa da arborização................................................. 17

3.4. Levantamento planimétrico................................................................ 18

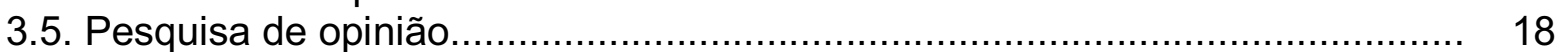

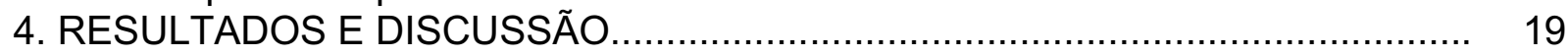

4.1. Levantamento histórico da Praça Sete de Setembro.................................... 19

4.2. A praça e seus eventos artísticos e culturais................................................ 33

4.3. Levantamento quali-quantitativo dos elementos arquitetônicos...................... 36

4.4. Análise quali-quantitativa da arborização.................................................... 48

4.5. Levantamento planimétrico................................................................... 54

4.6. Pesquisa de opinião....................................................................... 54

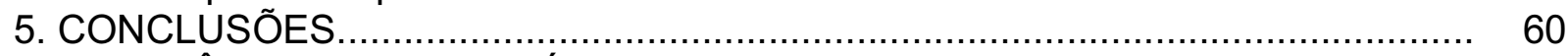

6. REFERÊNCIAS BIBLIOGRÁFICAS........................................................ 61 


\section{LISTA DE FIGURAS}

Figura 1. Figura utilizada no levantamento quantitativo dos elementos arquitetônicos da Praça Sete de Setembro do município de Ribeirão Preto, SP, adaptado de DE ANGELIS et al. (2004).

Figura 2. Figura utilizada no levantamento qualitativo dos elementos arquitetônicos da Praça Sete de Setembro do município de Ribeirão Preto, SP, adaptado de DE ANGELIS et al. (2004).

Figura 3. Questionário utilizado na pesquisa de opinião realizada na Praça Sete de Setembro, no município de Ribeirão Preto, SP, adaptado de DE ANGELIS (2000)... Figura 4. Foto de Manoel Aureliano de Gusmão. Fonte: Acervo bibliográfico da Câmara Municipal de Ribeirão Preto..

Figura 5. Documento de ratificação do nome da Praça Sete de Setembro para Aureliano de Gusmão em 1939. Fonte: Arquivo Público e Histórico de Ribeirão Preto.

Figura 6. Ata que comprova a mudança da denominação do nome da praça............. Figura 7. Documento que comprova a mudança na denominação da praça. Fonte: Arquivo Público e Histórico de Ribeirão Preto.....

Figura 8. Documento que comprova a retirada das grades da Praça Sete de Setembro. Fonte: Arquivo Público e Histórico de Ribeirão Preto.................................. Figura 9. Localização da Praça Sete de Setembro. Fonte: Arquivo Público e Histórico de Ribeirão Preto.

Figura 10. Levantamento planimétrico antigo (a) e recente realizado em outubro de 2009 (b)

Figura 11. Foto da Praça Sete de Setembro de 1956, extraída do Folheto "Praças e monumentos que contam histórias".

Figura 12. Lago da Praça Sete de Setembro, construído em 1996. Fonte: Ribeirão Vive o Verão.

Figura 13. Pintura feita por Therezinha Araújo Filippi Bonfá. Livro: Ribeirão Arte....... Figura 14. Folheto da Superintendência do Trabalho Artesanal das Comunidades (a), foto da feira de artesanato (b), foto de uma artesã inscrita na Casa da Cultura (c).

Figura 15. Galeria a Céu Aberto (a), expositor de pinturas e esculturas (b)................ Figura 16. Apresentação do Sexteto Colibri no coreto da Praça Sete de Setembro... Figura 17. Presença e nota dos elementos arquitetônicos encontrados na Praça Sete de Setembro, Ribeirão Preto, SP, 2010, adaptado de DE ANGELIS et al. (2004). 
Figura 18. Aspecto do banco da Praça Sete de Setembro, Ribeirão Preto, SP, 200938

Figura 19. Iluminação no entorno (a) e central da Praça Sete de Setembro (b)........ 39

Figura 20. Lixeira da Praça Sete de Setembro....................................................... 40

Figura 21. Telefones públicos protegidos por um quiosque.................................. 41

Figura 22. Aspecto do piso da praça............................................................ 41

Figura 23. Aspecto do coreto......................................................................... 42

Figura 24. Escultura na praça........................................................................... 43

Figura 25. Aspectos do pergolado da praça....................................................... 44

Figura 26. Ponto de táxi da Praça Sete de Setembro, Ribeirão Preto, SP, 2009...... 44

Figura 27. Ponto de táxi da Praça Sete de Setembro, Ribeirão Preto, SP, 2009...... 45

Figura 28. Banca de Revista da Praça Sete de Setembro, Ribeirão Preto, SP, 2009.

Figura 29. "Trailler" de lanches localizado na praça............................................. 46

Figura 30. Aspectos da forração da praça ......................................................... 47

Figura 31. Aspectos da praça suja (a) e limpa (b).............................................. 48

Figura 32. Aspectos da arborização da praça. Acervo particular de João Rossato.... 49

Figura 33. Macacos sagüis na Praça Sete de Setembro, Ribeirão Preto, SP............ 50

Figura 34. Freqüência de usuários segundo o sexo.......................................... 57

Figura 35. Faixa etária dos entrevistados.................................................... 57

Figura 36. Grau de escolaridade dos entrevistados......................................... 57

Figura 37. Atividade ocupacional dos entrevistados........................................ 57

Figura 38. Motivos de utilização da praça segundo os entrevistados...................... 60

Figura 39. O que os entrevistados mais gostam na praça.................................... 60

Figura 40. Mudança da infra-estrutura da praça ao longo dos anos........................ 60

Figura 41. Conhecimento do nome da Praça Sete de Setembro pelos entrevistados 60 


\section{LISTA DE ANEXOS}

Páginas

Anexo 1. Mapa planimétrico da Praça Sete de Setembro, Ribeirão Preto, SP...... 69

Anexo 2. Identificação das espécies arbóreas alocadas no mapa planimétrico...... 70 


\title{
ANÁLISE HISTÓRICO-CULTURAL, PAISAGÍSTICA E QUALI-QUANTITATIVA DOS ELEMENTOS ARQUITETÔNICOS DA PRAÇA SETE DE SETEMBRO, RIBEIRÃO PRETO, SP
}

\begin{abstract}
RESUMO - As praças são espaços públicos urbanos livres de edificações que tem a função de promover convivência sadia à população, oferecendo recreação e bem estar num ambiente agradável. Muitas praças foram implantadas há muitos anos; algumas passaram por reformas, no entanto, é importante que se faça uma análise periódica a fim de adequar às necessidades dos usuários. A Praça Sete de Setembro no município de Ribeirão Preto-SP, antes chamada por Aureliano de Gusmão, possui um diferencial das outras praças da cidade, proporciona usos diversos aos seus usuários. Com uma área de 16.619,41 $\mathrm{m}^{2}$, com grande diversidade de espécies arbóreas, promove conforto térmico bastante agradável aos seus freqüentadores, além de melhorar a qualidade de vida para aqueles que a utilizam. Desta forma este trabalho teve por objetivo fazer um levantamento histórico-cultural e paisagístico, bem como, fazer uma análise qualiquantitativa dos elementos arquitetônicos e da arborização da Praça Sete de Setembro, uma das mais freqüentadas da região central do município de Ribeirão Preto, SP. Foi feita uma pesquisa de opinião, aplicada na praça em dias da semana e horários diferentes, por meio de 100 questionários com perguntas diretas aos entrevistados. Concluiu-se que a Praça Sete de Setembro é usada para reunir e promover lazer a diferentes grupos de pessoas, preferencialmente do sexo feminino, de 21 a 40 anos, para descanso e passeio com as crianças; oferece aos seus usuários elementos arquitetônicos adequados e em bom estado de conservação e apresenta grande diversidade de espécies arbóreas (86 espécies num total de 281).
\end{abstract}

Palavras-chave: Arborização Urbana, Planejamento Urbano, Praça Pública 


\title{
HISTORICAL AND CULTURAL ANALYSIS, AND LANDSCAPE QUALI- QUANTITATIVE OF ARCHITECTURAL FEATURES OF SETE DE SETEMBRO SQUARE, RIBEIRÃO PRETO, SP
}

\begin{abstract}
The squares are urban public places without buildings that have the function to promote the population healthy living, offering recreation and wellness in a pleasant environment. Many squares have been implemented over many years ago, some have gone through renovations, however, it is important to make a periodic assessment in order to adapt them to the users' needs. The Sete de Setembro Square from Ribeirão Preto city, which had been called by Aureliano de Gusmão Square, has the edge on the others that is an active social life, being a plenty attractions scenario. The place has an area of $16,619.41 \mathrm{~m}^{2}$, owns a great tree species diversity, promotes thermal comfort to its users, as well as their life quality. Thus the aim of this work was to do a historical, cultural and landscaping survey, and also make a qualitative and quantitative analysis of its architectural features and the arborization rate from Sete de Setembro Square which is one of the most visited squares in Ribeirão Preto's downtown, SP. It was applied an opinion poll over different day times and different week days, through 100 questionaires, with direct questions. It was concluded that Sete de Setembro Square is visited by different people groups in order to have leisure, especially by women, people from 21 to 40 years old, to rest and let kids walk; offering to the visitors a suitable architectural features and well-conserved and a large diversity of tree species (87 species in a total of 281).
\end{abstract}

Key-words: Public Square, Urban Arborization, Urban Planning 


\section{INTRODUÇÂO}

Desde muito tempo, o homem vem trocando o meio rural pelo urbano. As cidades cresceram de forma muito rápida e desordenada, sem um planejamento adequado de ocupação, provocando vários problemas que interferem sobremaneira na qualidade de vida do homem que vive na cidade. A maioria da população vive nos centros urbanos necessitando, cada vez mais, de condições que possam melhorar a convivência dentro de um ambiente muitas vezes adverso.

Com o advento da era "desenvolvimentista" e da explosão imobiliária na década de 60 houve a perda dos jardins privados e a impermeabilização do solo, sendo que o patrimônio das áreas verdes das cidades ficou cada vez mais restrito a arborização das ruas, praças, parques e maciços florestais (MILANO e DALCIN, 2000).

As praças são espaços livres, públicos, urbanos, de manifestação social, cultural e política, destinados ao lazer e ao convívio da população. É um elemento urbano muito antigo, pois já nas cidades gregas do século VI a.C. ocorriam manifestações políticas nas chamadas "ágoras" (praça da cidade grega na Antiguidade clássica, onde se manifestava a cidadania), que nada mais eram que praças secas (sem vegetação) centrais. A história das praças está diretamente ligada à evolução histórica do paisagismo e dos costumes da época; atualmente, esses espaços são marcados pela globalização, com liberdade de formas, privilegiando o lazer e o bem estar, dando importância também ao caráter ecológico-ambiental (PIVETTA et al., 2008).

No entanto, observa-se que em muitas cidades brasileiras a função de promover lazer, aproximar e reunir as pessoas, por motivo cultural, econômico, político ou social tem se perdido ao longo dos tempos. Muitas vezes o que se vê, são espaços abandonados, esquecidos pelo poder público e pela população local.

Ribeirão Preto é um município do interior do estado de São Paulo. Nascida em 1856, a cidade ganhou impulso com a lavoura de café, cultivada pelos imigrantes italianos; o desenvolvimento trouxe novas culturas como a soja, o milho, o algodão, a 
laranja e a cana-de-açúcar e implantou uma forte agro-indústria, denominada "pólo tecnológico" pelo governo do estado de São Paulo.

O crescimento rápido do município de Ribeirão Preto segundo IBGE (2009), com uma população de 563.107 habitantes é muito preocupante, o aumento dos condomínios fechados desmatando o pouco que resta de matas, tem trazido sérios problemas à cidade. Anualmente a cidade sofre inundações em regiões consideradas importantes para o município.

O replanejamento das praças é importante para que se possa adequar às necessidades dos usuários, pois, muitas são antigas e nem passaram por reformas, ou, foram feitas interferências com pouco ou nenhum critério técnico.

Muitos estudos de praças brasileiras vêm sendo feitos como os realizados por PEGOLO e DEMATTÉ (2002), DE ANGELIS et al. (2005), MELO e ROMANINI (2008), SILVA et al. (2007), SILVA et al. (2008), BORELLA (2009). Estes estudos trazem grande benefício à população local e levantam questões de ordem geral que possibilita o avanço da discussão e consequentemente, do planejamento de novas praças.

A Praça Sete de Setembro, que antes foi chamada de Aureliano de Gusmão, é referência para a cidade, pois além de ser bastante antiga, é de grande importância para os ribeirão-pretanos, onde semanalmente acontecem feiras de artesanato, exposições e comércio de quadros e esculturas, e uma vez por mês apresentações musicais. O local possui uma área total de $16.619,41 \mathrm{~m}^{2}$, sendo bastante arborizado, promovendo uma qualidade de vida melhor para a população.

Desta forma, este trabalho tem como objetivo estudar a evolução históricocultural e paisagística, bem como fazer uma análise quali-quantitativa dos elementos arquitetônicos e da arborização da Praça Sete de Setembro, do município de Ribeirão Preto-SP. 


\section{REVISÃO DE LITERATURA}

\subsection{Paisagismo}

O termo paisagem surgiu na Holanda, no século XVI, para designar pinturas (GRIMAL, 1974). Para DEMATTÊ (1999), a palavra paisagem significa espaço de terreno que abrange um lance de vista, ou extensão territorial a partir de um determinado ponto. Segundo a mesma autora, em Geografia, paisagem é o resultado atual de um longo processo evolutivo, como a formação de relevo de determinada região, seu clima, a vida que ali se instalou e evoluiu, a interferência humana e as interações entre esses fatores.

SEGAWA (1996) classifica a paisagem como consciência humana diante de um ambiente, produto de seu potencial imaginativo e criador, uma contemplação visual formulando significados e novas imagens. Neste conceito, o autor classifica os jardins como sendo o enquadramento de paisagens cultivadas pelo homem com uma presença marcante de vegetação no imaginário.

Para ABBUD (2006), o paisagismo é a única expressão artística em que participam os cinco sentidos do ser humano, o que proporciona uma rica vivência sensorial, ao somar as mais diversas e completas experiências perceptivas.

No Brasil, na primeira metade do século XVII, surgiu em Pernambuco uma manifestação de paisagismo por meio do Governador Geral do Brasil (Mauricio Nassau) em que foram plantadas espécies de frutíferas como laranjeiras, tangerineiras e limoeiros (PAIVA e ALVES, 2002).

A introdução do paisagismo no Brasil foi tardia se comparada ao que ocorreu no mundo oriental. Os primeiros grandes espaços verdes só apareceram no século XVIII como o Passeio Público do Rio de Janeiro, um antigo charco que foi aterrado e ajardinado em 1783 (FARIA, 2005; PAIVA e ALVES, 2002; VILAS BOAS, 1999).

O Passeio Público é, oficialmente, o mais antigo parque urbano do Brasil destinado a servir à população. Criado por ordem do vice-rei Luís de Vasconcelos de Souza, foi projetado por mestre Valentim da Fonseca e Silva segundo um traçado 
extremamente geométrico, inspirado nas tradições de desenho do jardim clássico francês (MACEDO e SAKATA, 2003).

A história documentada do paisagismo no Brasil iniciou-se com a chegada de Dom João VI, em 1807, que destinou ao Jardim Botânico do Rio de Janeiro a vocação de cultivar espécies para a produção de carvão, matéria-prima para a fabricação de pólvora. O grande marco do paisagismo no país foi o surto de nacionalismo decorrente do pós-guerra. Seguindo esta linha, chegariam aos jardins as idéias do paisagista Burle Marx, defendendo o uso da flora tropical (FARIA, 2005).

O parque urbano, no Brasil, nasceu no século XIX, com a necessidade de se adotarem espaços adequados para atenderem a uma nova demanda social como, por exemplo, o lazer, o tempo do ócio e a necessidade de melhorar o ambiente urbano. $\mathrm{O}$ papel dos parques no país é muito abrangente e sua definição nem sempre é precisa. Muitas vezes, são espaços de lazer de pequeno porte (um hectare ou um pouco mais), sendo denominados parques porque são cercados e têm instalações de lazer e vegetação (MACEDO e SAKATA, 2003).

\subsection{Espaços Livres}

Para MACEDO (1993), os espaços livres são todos aqueles não contidos entre as paredes e tetos dos edifícios construídos pela sociedade para sua moradia e trabalho e por onde as pessoas se movimentam no cotidiano urbano. Portanto, ruas, praças, pátios, parques, jardins e etc, são espaços livres contidos nas cidades.

O espaço livre é um elemento funcional do plano que deve ser distribuído eqüitativamente na cidade, tendo em vista o uso da população. Estes espaços têm a função de tornar mais pura a atmosfera das cidades e proporcionar, para a população local, espaços para a prática da cultura física e dos passeios. Podem ser agrupados segundo sua função: vias de comunicação largas e rotatórias; as praças, por sua relação com os edifícios e monumentos; as áreas destinadas a recreação, passeios, distração e repouso, como os jardins botânicos, zoológicos e determinados parques; e outras áreas reservadas à pratica de esportes (LEFEVRE, 1952). 
Espaço livre para LIMA et al. (1994), é a integração dos demais espaços contrapondo-se ao espaço construído, nas áreas urbanas. Assim, a Floresta Amazônica não se inclui nessa categoria, diferente da Floresta da Tijuca, pois se localiza dentro da cidade do Rio de Janeiro, portanto, é um espaço livre.

\section{3. Áreas verdes}

É denominado de área verde o espaço onde há o predomínio de vegetação arbórea, englobando as praças, os jardins públicos e os parques urbanos. Os canteiros centrais de avenidas, os trevos e rotatórias de vias públicas, que exercem funções estéticas e ecológicas, devem também conceituar-se como área verde (LIMA et al., 1994).

Segundo DEMATTÊ (1999), o termo área verde aplica-se a diversos tipos de espaços urbanos que tem em comum o fato de serem abertos, acessíveis e relacionados à saúde e recreação. Para PAIVA e GONÇALVES (2002), os espaços livres ou abertos podem ser planejados para se tornarem uma área verde quando a vegetação se apresenta em significativas extensões.

Considerar a existência de benefícios econômicos e sociais das árvores nas cidades é apenas um processo lógico, uma vez que existem benefícios de ordem ecológica (clima e poluição), biológica (saúde física do homem) e psicológica (saúde mental do homem) (MILANO e DALCIN, 2000).

As áreas verdes urbanas proporcionam melhorias no ambiente excessivamente impactado das cidades e benefícios para os habitantes das mesmas. A função ecológica deve-se ao fato da presença da vegetação, do solo não impermeabilizado e de uma fauna mais diversificada nessas áreas, promovendo melhorias no clima da cidade e na qualidade do ar, água e solo. A função social está relacionada com a possibilidade de lazer que essas áreas oferecem população (GUZZO, 2009a).

As praças são representações de áreas verdes tendo como finalidade principal o lazer. Uma praça pode não ser considerada como área verde quando não possuir vegetação em seu perímetro. Quando impermeabilizadas são denominadas como 
espaços duros ou praças secas e quando apresenta vegetação são comumente denominadas de jardim (GUZZO, 2009b).

\subsection{A praça}

A praça como espaço público constitui, desde os seus primórdios, em um referencial urbano marcado pela convivência humana. É, portanto, um importante equipamento histórico e cultural urbano que expressa $o$ surgimento $e$ o desenvolvimento de inúmeras cidades, especialmente, no Brasil (GOMES, 2005).

Para SEGAWA (1996), "a praça é um espaço ancestral que se confunde com a própria origem do conceito ocidental urbano".

De acordo com o "Diccionario de la lengua española, plaza" constitui um "lugar espaçoso dentro do povoado". Em outro dicionário espanhol, de Sebastian Covarrubias de 1611 - "Tesoro de la lengua castellana" - aparece a mesma definição, porém acrescida do termo "lugar público". Ainda, uma outra definição é comum em ambos dicionários quando identificam a praça como local onde "se vendem os mantimentos e se tem o comércio dos moradores locais com os vizinhos da região, e onde se celebram as feiras, os mercados e festas públicas" (SEGAWA, 1996).

O termo praça implica inúmeras definições, tanto por parte do poder público, quanto de pesquisadores e técnicos, tendo em vista a amplitude e variedade de idéias dos diversos estudiosos (GOMES, 2005).

Para SOUZA (2005), as praças são unidades urbanísticas fundamentais para a vida urbana e o seu modo de tratamento e uso indicam o nível de civilidade de seus usuários e o exercício dos direitos e deveres de cidadania nela vivenciados. É pelo uso que as pessoas fazem de uma praça um espaço importante para o seu dia-a-dia e convívio social.

Do romantismo à praticidade, conceitos e funções sobre as praças existem os mais diversos; porém, todos têm um ponto em comum: é o local da reunião, do encontro. Na década de 50 , as praças eram consideradas locais onde as pessoas se 
reuniam para desenvolver atividades comerciais, políticas ou religiosas, ou ainda, onde se desenvolviam atividades de entretenimento (RIGOTTI, 1956).

As praças ajardinadas eram antigamente destinadas às atividades de recreação, ao lazer contemplativo, a convivência da população e ao passeio, "possuindo algumas normas de conduta e comportamento bastante rígidas e hierarquizadas". A praça moderna engloba áreas de lazer ativo, com quadras poliesportivas e brinquedos para as crianças, requeridas pela própria sociedade (ROBBA e MACEDO, 2003).

A função da praça alterou-se ao longo do tempo. Na antiguidade, sua função era mais rica de significado, não se limitando a um lugar de cruzamento de vias públicas, estacionamento para automóveis ou de ponto para comércio de mercadorias. Esse estreitamento de sua função deu-se a partir do momento em que as estruturas logísticas dos mercados, a troca de informação e a própria informatização, aliadas ao processo de globalização, além do poder com seus meios e seus símbolos, distanciaram-se da dimensão comunitária da coletividade, e se aproximaram do privado na sua dimensão familiar, se não, ao seu isolamento individual. Além do significado social, a praça também tem o significado de espaço da memória histórica que foi palco para discursos políticos e culturais sobre a cidade como um local de identidade, de tradição, de saber, de autenticidade, de continuidade e estabilidade (DE ANGELIS et al., 2005).

As praças medievais foram classificadas por Paul Zucker, em 1959, em praças de mercado (destinadas às atividades comerciais), praças no portal da cidade (constituíam áreas de passagem e distribuição de tráfego), praças como centro da cidade (implantadas em comunidades novas), adros de igrejas (destinadas às atividades religiosas) e praças agrupadas (composta por espaços de conexão entre praças de mercado e adros de igrejas) (ROBBA e MACEDO, 2002).

No fim da Idade Média e do Renascimento, a praça pública constituía um ambiente de liberdade, franqueza e familiaridade. "Era o ponto de convergência de tudo que não era oficial, de certa forma gozava de um direito de 'extraterritorialidade' no mundo da ordem e da ideologia oficiais, e o povo ai tinha sempre a última palavra" (SEGAWA, 1996). 
As praças contemporâneas são reflexos da diversidade cultural da sociedade atual. Tais praças assumiram elementos, desenhos, cores, materiais e formas variadas. Além do uso contemplativo, da convivência social e do lazer ativo, destaca-se a atividade comercial, numa tentativa de atrair para as praças um público maior (ROBBA e MACEDO, 2003).

Com o surgimento de outras formas alternativas de lazer e novos locais para o estabelecimento do comércio e associado ao descaso persistente do poder público frente à manutenção das praças, essas passaram a constituir-se apenas um fragmento a mais dentro da malha urbana (DE ANGELIS e ANGELIS NETO, 2000).

Com as mudanças, as praças foram deixando de ser um espaço prioritário de recreação. A maioria das pessoas tem outras necessidades e sentem o mundo ao seu redor de modo diferente. Isso não significa que os espaços verdes urbanos precisem cair no esquecimento, pois são ecologicamente importantes, possuem valores estéticos além de auxiliarem na redução da amplitude térmica, e novos usos podem ser estendidos a eles, com equipamentos adequados. Instigando-se novas formas de percepção do ambiente urbano, seria possível ampliar as relações positivas da população com a paisagem. O apreço pelos espaços verdes poderia ser resgatado, mesmo que as pessoas não mais se utilizassem deles da forma como faziam antes. Dois pontos não devem ser esquecidos: a constante participação do poder público e a conscientização (PEGOLO e DEMATTÊ, 2002).

Segundo QUEIROGA (2004), a praça é menos popular, mas, nem por isso, deixou de ter importância. Não existem mais bandas tocando nos coretos das praças das grandes cidades; nas noites, algumas são pontos de prostituição, outras acolhem bêbados e drogados. Em cidades pequenas e médias é ainda muito freqüente o encontro após a missa, bailes e até bingo beneficente. Assim, as praças contemporâneas, são reflexos da diversidade cultural da sociedade atual.

É importante observar que o significado da praça para as comunidades de baixa renda é algo intrínseco à própria condição de existência das pessoas enquanto cidadãos, pois necessitam de refúgio do lar, de contato com a vizinhança, de lazer e de ar livre, é um local para convivência e lazer do cotidiano urbano (GOMES, 2005). 
Nos grandes centros, são encontradas, com facilidade, praças deterioradas pouco freqüentadas devido à diversidade de problemas que envolvem tais espaços. Isso constitui para os planejados, uma importante questão no que se refere à qualidade da paisagem urbana e à valorização dos espaços públicos (GOMES, 2005).

DE ANGELIS (2000), relatou que a imagem inicial fixada com freqüência desses espaços é de pobreza e abandono, muitas vezes utilizados como estacionamentos ou cercados por grades. As praças sucumbem sob o peso de um urbanismo selvagem em detrimento do lazer e do interesse coletivo. Diante desta realidade, rouba-se da população um espaço nobre, essa por sua vez não protesta pelo espaço que se esvai. É a cumplicidade passiva da população que colabora com as atitudes dos gestores públicos com o descaso com a "coisa pública".

\subsection{A evolução das praças no Brasil}

Ao longo da história urbana brasileira, as praças desempenharam papéis diferenciados na sociedade. Ora civicamente, ora militarmente, esses logradouros se destacavam nas cidades pelas funções que exerciam. Durante muito tempo, funções como essas deram significado desses espaços públicos, tidos como símbolo do poderio estatal e religioso (GOMES, 2005). Conforme bem destaca MARX (1980), "uma igreja, uma praça; regra geral nas nossas povoações antigas".

Apesar de raras, mas marcantes, as praças cívicas brasileiras surgiram em pequeno número e representam símbolos da história política do país. Sempre diante de edifícios públicos, "são logradouros que transcendem o uso e o significado local, interessando a todos nós" (MARX, 1980).

Como grandes exemplos de praças que marcaram a história política no Brasil, encontram-se: Praça Municipal de Salvador, Praça XV de Novembro no Rio de Janeiro e a Praça dos Três Poderes em Brasília, exatamente as três cidades que se tornaram sede, em momentos distintos, do Governo Federal (GOMES, 2005).

Nas praças coloniais brasileiras realizavam-se todas as atividades no mesmo espaço, inclusive civis e militares. Nesse contexto, as praças eram denominadas de 
largo, terreiro e rossio, e permitiam a interação dos vários estratos da sociedade, servindo como palco de manifestações de costumes e hábitos da sociedade colonial (ROBBA e MACEDO, 2002).

No Brasil, especialmente nos pequenos núcleos urbanos a imagem urbana permanece associada à presença do espaço público "praça". Assim, ainda é bastante comum associar o centro de uma cidade à presença da principal praça, bem como da igreja católica. Isso remete a considerar esses dois elementos como referenciais urbanos da área central de uma cidade. Esse fato pode ser constatado em pequenos, médios e grandes centros urbanos. Logo, a Praça da Sé, em São Paulo, a Praça da República, em Belém, a Praça XV de Novembro, em Ribeirão Preto e a Praça Nove de Julho em Presidente Prudente constituem referenciais urbanos destas cidades de portes diferentes (GOMES, 2005).

Os desenhos das praças públicas evoluíram através dos tempos conforme as funções que as mesmas desempenharam. Diversas correntes surgiram entre os arquitetos e paisagistas brasileiros no intuito de reestruturar esses espaços sob novas concepções à medida que a sociedade evoluía em seus hábitos, costumes e valores (GOMES, 2005). Nesse sentido, as linhas de projetos encontradas com maior freqüência nas praças públicas do Brasil, conforme identificam ROBBA e MACEDO (2002) são a eclética, a moderna e a contemporânea.

Os projetos ecléticos dividiram-se basicamente em duas linhas: a clássica e a romântica. Os projetos românticos são raros e restringiram-se aos parques e jardins de maior porte. Ao contrário, a linha clássica difundiu-se rapidamente e passou a caracterizar grande parte dos espaços livres públicos brasileiros (GOMES, 2005).

ROBBA e MACEDO (2002) descrevem os diversos elementos característicos das linhas de projetos de espaços livres públicos. Assim, os projetos ecléticos clássicos caracterizam-se pela presença de elementos como:

Traçados em cruz e variações;

- Estar central com ponto focal;

- Passeio perimetral;

- Canteiros geométricos; 
- Parterres (jardins de formas ornamentais complexas que se utilizam da arte topiária), simetria, eixos;

- Grandes quantidades de áreas permeáveis;

- Elementos ecléticos pitorescos (coretos, pavilhões, espelhos d'água, estátuas, monumentos, fontes, bustos);

- Vegetação arbustiva e forrações, dispostas como bordadura dos canteiros e caminhos;

- Vegetação arbórea plantada ao longo dos caminhos para sombreamento;

- Grande utilização de espécies exóticas européias e pequena utilização de espécies nativas;

- Geometrização e simetria no plantio da vegetação;

- Gramados, poda topiária.

O estilo eclético romântico, de acordo com ROBBA e MACEDO (2002), apresenta, em geral, os seguintes elementos:

- Traçados orgânicos e sinuosos (rompimento com escolas clássicas de composição);

- Estares e recantos contemplativos;

- Passeios e caminhos que percorrem toda a área;

- Lagos serpenteantes;

- Equipamentos ecléticos pitorescos (coretos, pavilhões, espelhos d'água, estátuas, monumentos, fontes, grutas, arcos, templos, malocas, castelos, entre outros);

- Grande quantidade de áreas permeáveis;

- Criação de cenários naturalistas;

- Criação de visuais;

- Utilização cênica da vegetação;

- Imitação d ambiente natural, naturalismo;

- Aplicação de forrações, vegetação arbustiva e arbórea mais exuberante, de forma a criar cenários; 
- Uso de espécies exóticas européias e de espécies nativas.

ROBBA e MACEDO (2002) relatam que a praça moderna surge adaptada às novas necessidades de lazer impostas pela urbanização vivenciada pelo país ao longo do século $\mathrm{XX}$, incorporou um programa misto com predominância do lazer ativo, atendendo a faixas etárias cada vez mais diversificadas.

As características que identificam a praça moderna conforme os mesmos autores, são:

- Setorização das atividades;

- Utilização de formas orgânicas, geométricas e mistas para pisos, caminhos, canteiros e espelhos d'água;

- Liberdade na composição formal, respeitando os dogmas modernistas;

- Grandes área de pisos processados;

- Criação de estares e recanto como elementos centrais de projeto;

- Circulações estruturadas por sequência de estares;

- Valorização de ícones e signos da cultura nacional e regional;

- Vegetação utilizada como elemento tridimensional de configuração de espaços;

- Plantio em maciços arbóreos e arbustivos, formando planos verticais;

- Plantio de forrações como grandes tapetes;

- Larga utilização e valorização da flora nativa e tropical.

\subsection{Benefícios das praças}

Para GUZZO (1999), a vegetação nas cidades é um importante indicador de qualidade ambiental. Muitas são suas contribuições no sentido de mitigar as alterações provocadas pelo processo de urbanização e industrialização.

LOMBARDO (1990) relata a importância da cobertura vegetal em relação à dinâmica do ambiente urbano:

- Composição atmosférica: ação purificadora por fixação de poeiras, materiais residuais, depuração bacteriana e de outros microrganismos, 
reciclagem de gases por meio de mecanismos fotossintéticos e por fixação de gases tóxicos.

- Equilíbrio solo-clima-vegetação: quanto à luminosidade e temperatura, a vegetação filtra a radiação solar e suaviza as temperaturas extremas, contribui para conservar a umidade do solo atenuando sua temperatura; reduz a velocidade do vento, mantém as propriedades do solo permeabilidade e fertilidade, abriga à fauna existente e influencia no balanço hídrico.

- Níveis de ruído: amortecimento dos ruídos ocorrentes nas grandes cidades.

- Estético: quebra da monotonia da paisagem das cidades causada pelos grandes complexos de edificações, valorização visual e ornamental do espaço urbano, caracterização e sinalização de espaços constituindo-se em um elemento de interação entre as atividades humanas e o meio ambiente.

LOMBARDO (1990) relata ainda que "as árvores e outros vegetais, interceptando, absorvendo, refletindo e transmitindo radiação solar (diminui a ilha de calor na cidade), captando e transpirando água e interferindo com a direção e velocidade dos ventos, podem ser extremamente eficientes na melhoria do clima urbano".

Para DEMATTÊ (1999), uma cobertura arbórea bem suprida de água pode reduzir a temperatura em um dia quente e seco, em até $3,5^{\circ} \mathrm{C}$.

Os benefícios das praças com áreas verdes em centros urbanos contribuem para a melhoria da qualidade do ar por meio da retenção de elementos particulados em suspensão na atmosfera e absorção de gases poluentes (SCHUBERT, 1979; ROBERTS, 1980). A interceptação dos raios solares, bem como de ventos dominantes, é outro benefício resultante da presença de árvores nas cidades (GREY e DENEKE, 1978).

A vegetação presente nas praças não somente exerce influência sobre o ambiente físico do local, mas também influencia individualmente sobre a saúde física e 
mental dos habitantes dos centros urbanos. Benefícios sociais como espaço para recreação ao ar livre e até mesmo valorização econômica de espaços urbanos podem estar relacionados à arborização (BARTENSTEIN, 1981). A capacidade única das árvores em controlar muitos dos efeitos adversos das cidades, contribuindo para significativa melhoria da qualidade de vida, determina a existência de uma crescente necessidade de áreas verdes urbanas a serem manejadas como recurso de múltiplo uso em prol de toda a comunidade (JOHNSTON, 1985).

\subsection{Ribeirão Preto}

Ribeirão Preto é um município do interior do Estado de São Paulo, situa-se a $21^{\circ}$ 12' 42" de latitude sul e $47^{\circ} 48^{\prime}$ '24" de longitude oeste, distante 313 quilômetros a noroeste da capital estadual e a 706 quilômetros de Brasília. Seu território de 652 km² abriga uma população estimada em 563.107 habitantes (IBGE, 2009).

O povoado de São Sebastião do Ribeirão Preto foi fundado em 19 de junho de 1856, isso ocorreu com as doações de terras feitas para a construção da capela à São Sebastião. A capela foi construída entre os dois mananciais de água, Ribeirão Preto e Córrego de Retiro. No ano de 1889, pela Lei Provincial $n^{\circ} 88$ em primeiro de abril, o povoado foi elevado à categoria de cidade (CIONE, 1987).

A cidade ganhou impulso com a lavoura de café, cultivada pelos imigrantes italianos; na virada do século XIX, a região era considerada a maior produtora de grãos, abastecendo o mundo inteiro com o que se chamava "ouro verde". O desenvolvimento trouxe novas culturas como a soja, o milho, o algodão, a laranja e a cana-de-açúcar e implantou uma forte agro-indústria, denominada "pólo tecnológico" pelo governo do estado de São Paulo (HISTÓRICO DE RIBEIRÃO PRETO, 2009; RIBEIRÃO PRETO, 2009). 


\section{MATERIAL E MÉTODOS}

O trabalho foi realizado na Praça Sete de Setembro, localizada na região central do município de Ribeirão Preto, SP, entre as ruas Sete de Setembro, Floriano Peixoto, Lafaiete e Florêncio de Abreu, no período de Agosto de 2009 à Janeiro de 2010, sendo dividido em cinco etapas:

\subsection{Levantamento histórico e documental da Praça Sete de Setembro}

O levantamento histórico foi realizado no Arquivo Público e Histórico de Ribeirão Preto, na Casa da Cultura, no Museu da Imagem e Som e acervos bibliográficos da Câmara Municipal de Ribeirão Preto.

\subsection{Levantamento quali-quantitativo dos elementos arquitetônicos}

O levantamento foi baseado na metodologia proposta por DE ANGELIS et al. (2004). Para a análise quantitativa dos elementos arquitetônicos foi utilizada a Figura 1 , onde foram assinaladas a presença ou ausência dos elementos arquitetônicos que compõe a praça. Foram ainda quantificados e, sempre que possível, determinou-se o material com o qual foram confeccionados.

Para análise qualitativa dos elementos arquitetônicos, utilizou-se a Figura 2, sendo avaliado o estado de conservação das estruturas e equipamentos existentes. Foram utilizados os seguintes conceitos: péssimo (nota de 0 - 0,5), ruim (nota de 0,5 $1,5$ ), regular (nota $1,5-2,5)$, bom $(2,5-3,5)$ e ótimo (nota $3,5-4,0$ ). 


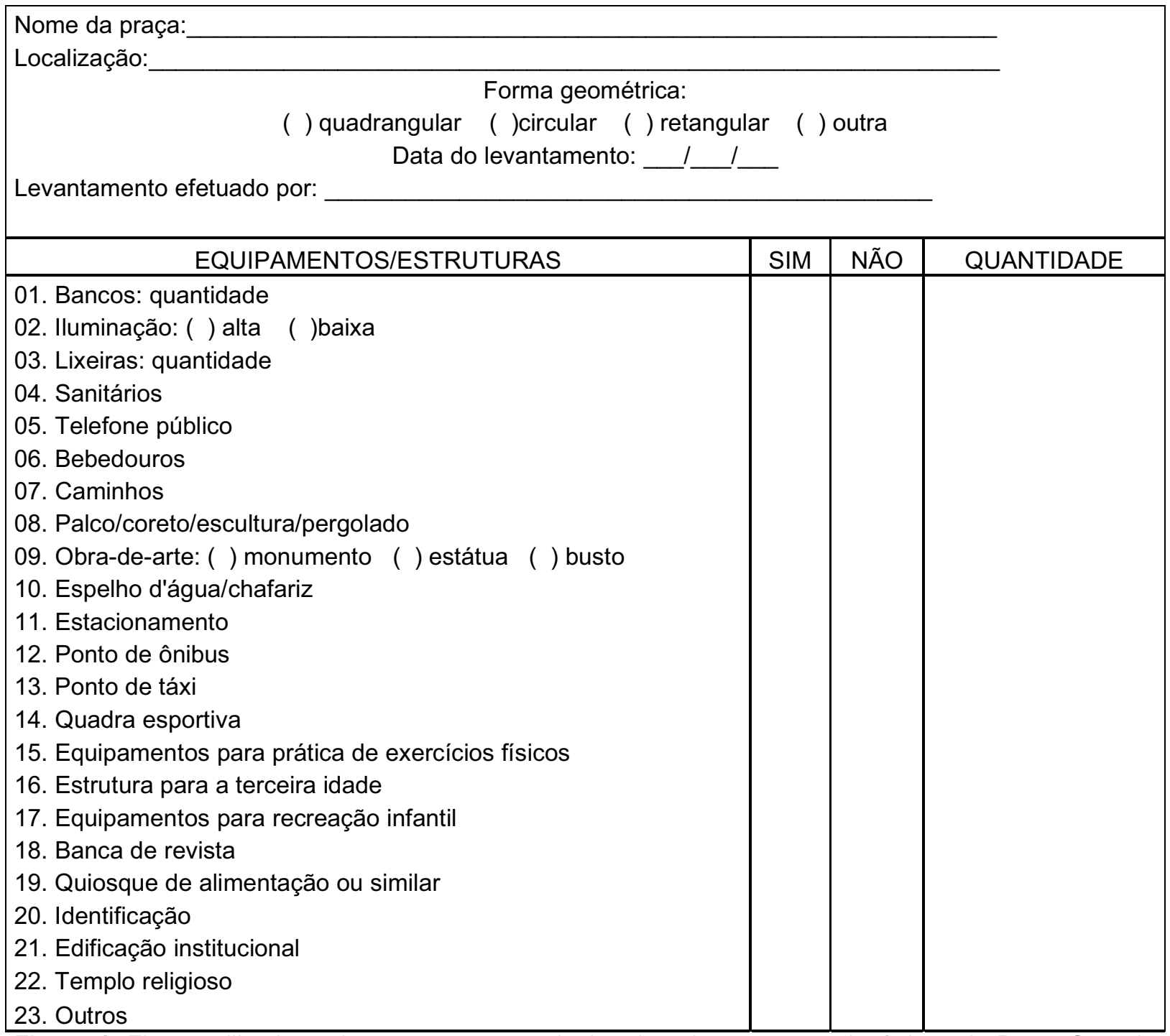

23. Outros

Figura 1. Figura utilizada no levantamento quantitativo dos elementos arquitetônicos da Praça Sete de Setembro do município de Ribeirão Preto, SP, adaptado de DE ANGELIS et al. (2004). 


\begin{tabular}{|c|c|c|}
\hline ESTRUTURAS AVALIADAS & NOTA & AUSÊNCIA \\
\hline $\begin{array}{l}\text { 01. Bancos } \\
\text { 02. lluminação alta } \\
\text { 03. lluminação baixa } \\
\text { 04. Lixeiras } \\
\text { 05. Sanitários } \\
\text { 06. Telefone público } \\
\text { 07. Bebedouros } \\
\text { 08. Piso } \\
\text { 09. Traçado dos caminhos } \\
\text { 10. Palco/coreto/escultura } \\
\text { 11. Pergolado } \\
\text { 12. Monumento } \\
\text { 13. Espelho d'água/chafariz } \\
\text { 14. Estacionamento } \\
\text { 15. Ponto de ônibus } \\
\text { 16. Ponto de táxi } \\
\text { 17. Quadra esportiva } \\
\text { 18. Equipamentos para exercícios físicos } \\
\text { 19. Estrutura para terceira idade } \\
\text { 20. Parque infantil } \\
\text { 21. Banca de revista } \\
\text { 22. Quiosque para alimentação e/ou similar } \\
\text { 23. Vegetação } \\
\text { 24. Paisagismo } \\
\text { 25. Localização } \\
\text { 26. Conservação/Limpeza } \\
\text { 27. Segurança } \\
\text { 28. Conforto ambiental }\end{array}$ & & \\
\hline
\end{tabular}

Figura 2. Figura utilizada no levantamento qualitativo dos elementos arquitetônicos da Praça Sete de Setembro do município de Ribeirão Preto, SP, adaptado de DE ANGELIS et al. (2004).

\subsection{Análise quali-quantitativa da arborização}

Foi realizado um levantamento das espécies vegetais arbóreas encontradas na praça e calculada a frequência relativa para cada espécie. 


\subsection{Levantamento planimétrico}

Para obter a planta baixa e a localização das espécies, foi feito o levantamento planimétrico. A identificação das espécies foi feita a campo e a classificação com base na literatura (CRONQUIST, 1988; LORENZI, 1992; 1998).

Foi utilizado o teodolito da marca "TOPCON", modelo GTS-701, com precisão angular de $00^{\circ} 00^{\prime} 03^{\prime \prime}$. A vegetação foi inserida nesse levantamento, juntamente com a locação da praça.

\subsection{Pesquisa de opinião}

Foi realizada uma pesquisa de opinião com 100 pessoas presentes na praça, em dias da semana e horários diferentes, para conhecer a importância e a utilização do local pelos frequentadores. Utilizou-se um questionário (Figura 3) adaptado ao proposto pelo método de DE ANGELIS (2000). 
1. Idade

( ) $0-20$ ( ) $21-40$ ( ) $41-60$ ( ) Mais de 60

2. Sexo

( ) $\mathrm{M} \mathrm{(} \mathrm{)} \mathrm{F}$

3. Nível escolar

( ) Fundamental ( ) Médio ( ) Superior

4. Atividade ocupacional

( ) Trabalhador ( ) Estudante ( ) Aposentado ( ) Dona de casa

( ) Desempregado

5. Você freqüenta essa praça?

( ) Sim ( ) Não - Por quê?

6. Quais dias da semana você vai à praça?

( ) Durante a semana ( ) Sábado ( ) Domingo ( ) Feriado

7. Em que período você vai com mais freqüência à praça?

( ) Manhã ( ) Tarde ( ) Noite

8. Em média, qual é o seu tempo de permanência na praça?

9. Qual (is) o motivo que o leva à uma praça?

( ) Tomar sol ( ) Caminhar ( ) Ler ( ) Levar criança ( ) Descansar

( ) Praticar esporte ( ) Outros

10. $O$ que você mais aprecia e menos aprecia no local?

11. O que você acha que é necessário melhorar nas praças que frequenta?

12. Qual é a sua opinião sobre as praças da sua cidade?

13. Qual a mudança na infra-estrutura da praça, no decorrer dos anos?

( ) Melhorou ( ) Piorou - Por quê?

14. Conhece o nome dessa praça?

15. Conhece a história dessa praça?

Figura 3. Questionário utilizado na pesquisa de opinião realizada na Praça Sete de Setembro, no município de Ribeirão Preto, SP, adaptado de DE ANGELIS (2000).

\section{RESULTADOS E DISCUSSÃO}

\subsection{Levantamento histórico da Praça Sete de Setembro}

A Praça Sete de Setembro antes fora denominada Praça Aureliano de Gusmão em homenagem a Manoel Aureliano de Gusmão (Figura 4), que nasceu em 19 de setembro de 1857. Formou-se em direito pela Faculdade de Direito de Recife, PE, em 1880. Foi advogado, senador estadual, jurista e professor. Ocupou cargos importantes como, o primeiro juiz de direito da Comarca de Ribeirão Preto, vereador, vice- 
presidente da Câmara e Intendente Municipal (eleito em 05 de julho de 1902). Criou a lei que substituiu a denominação de Intendente (figura da administração pública de origem francesa) para Prefeito, aprovada em 22 de novembro de 1902, sem que suas funções fossem alteradas, sendo ele o último chefe do executivo municipal denominado de Intendente. Seu mandato iniciou-se em 05 de julho de 1902 como Intendente, finalizando em 03 de outubro de 1903 como Prefeito (RIBEIRÃO PRETO - CÂMARA MUNICIPAL, 1811-1930).

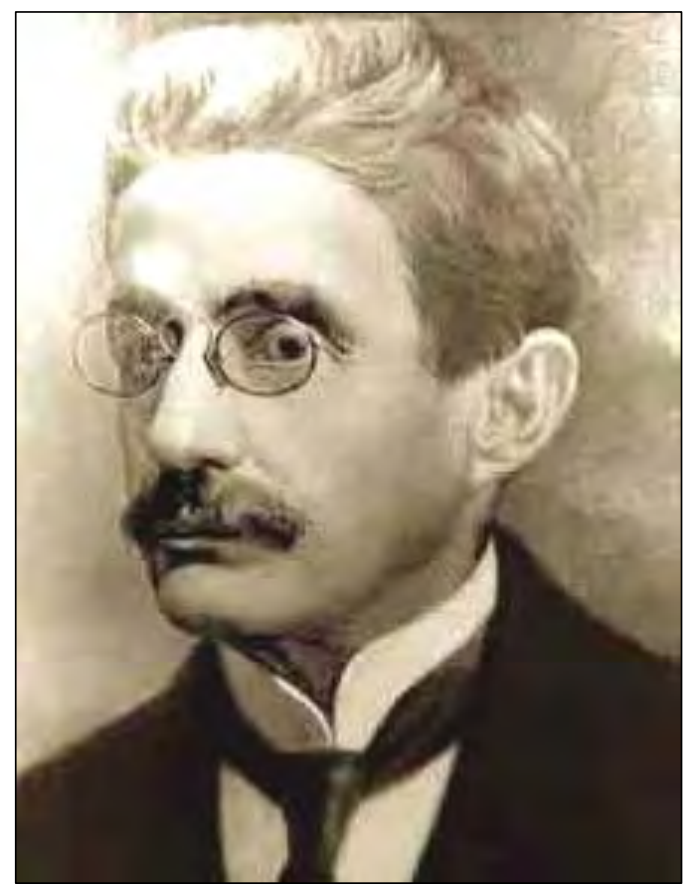

Figura 4. Foto de Manoel Aureliano de Gusmão. Fonte: Acervo bibliográfico da Câmara Municipal de Ribeirão Preto.

Não foi encontrado documentos datando a primeira nomeação (Praça Aureliano de Gusmão) à praça.

O documento da figura 5 reforça a nomenclatura da praça, pois em 1939, já era chamada de Sete de Setembro. 


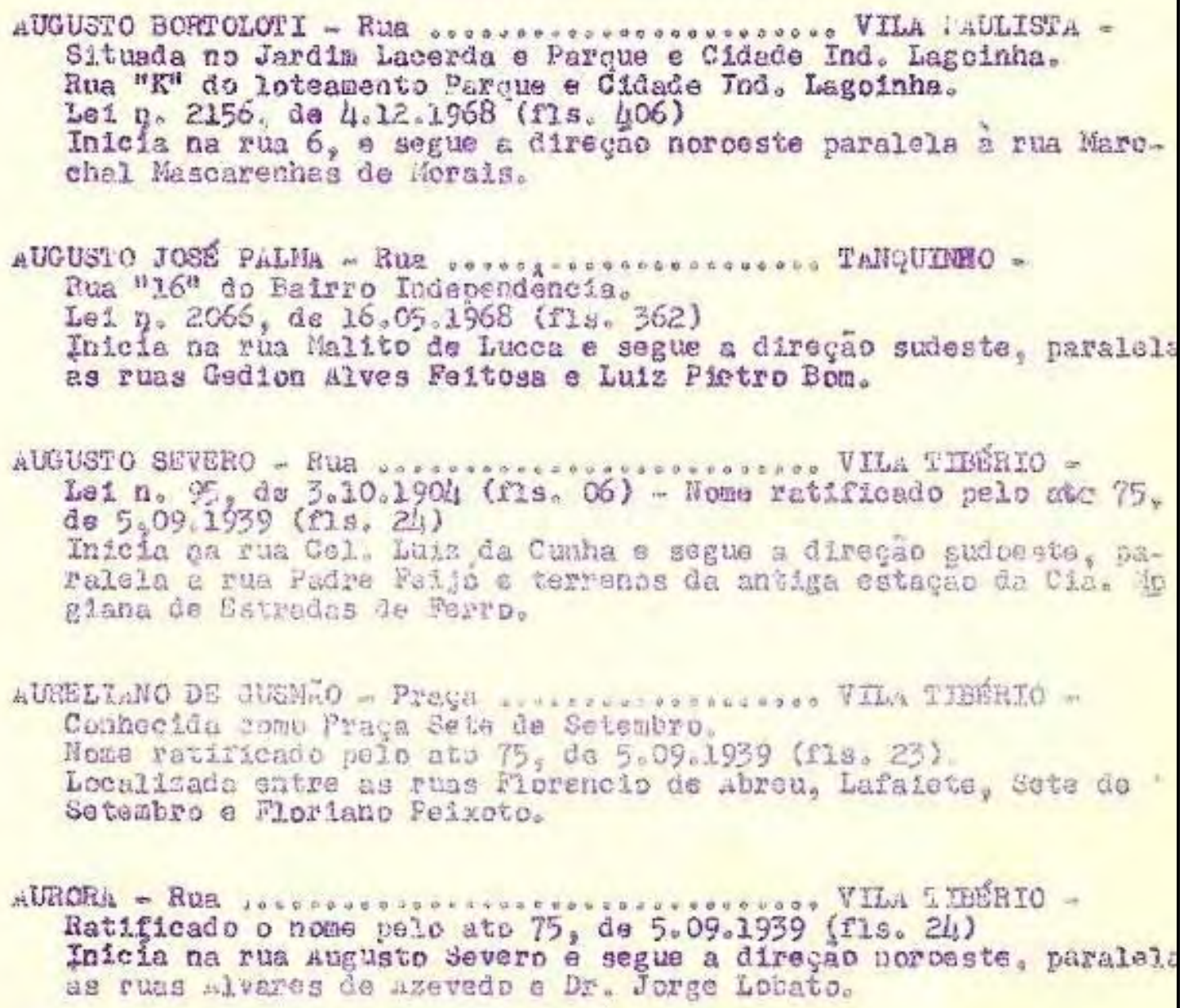

Figura 5. Documento de ratificação do nome da Praça Sete de Setembro para Aureliano de Gusmão em 1939. Fonte: Arquivo Público e Histórico de Ribeirão Preto.

Em 1972 a Câmara Municipal de Ribeirão Preto aprova a lei que autoriza a alteração da denominação da Praça Aureliano de Gusmão para Praça Sete de Setembro (Figura 6 e 7), e reserva o topônimo "AURELIANO DE GUSMÃO" para servir de denominação a uma praça pública existente e sem nomenclatura ou a ser construída futuramente neste Município. O prefeito que ocupava o cargo na época era Antônio Duarte Nogueira. O topônimo permanece reservado até os dias de hoje. 


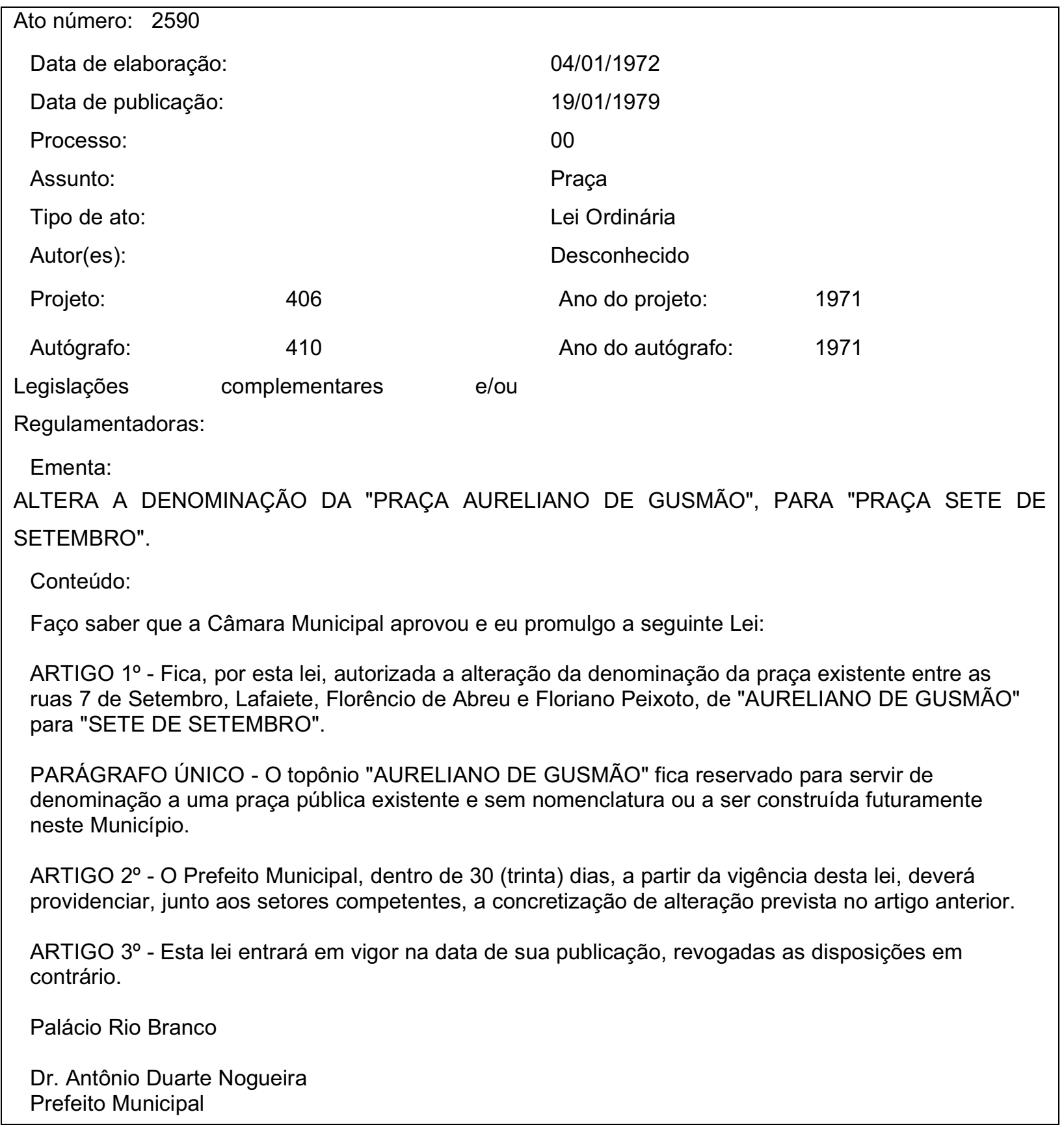

Figura 6. Ata que comprova a mudança da denominação do nome da praça. 


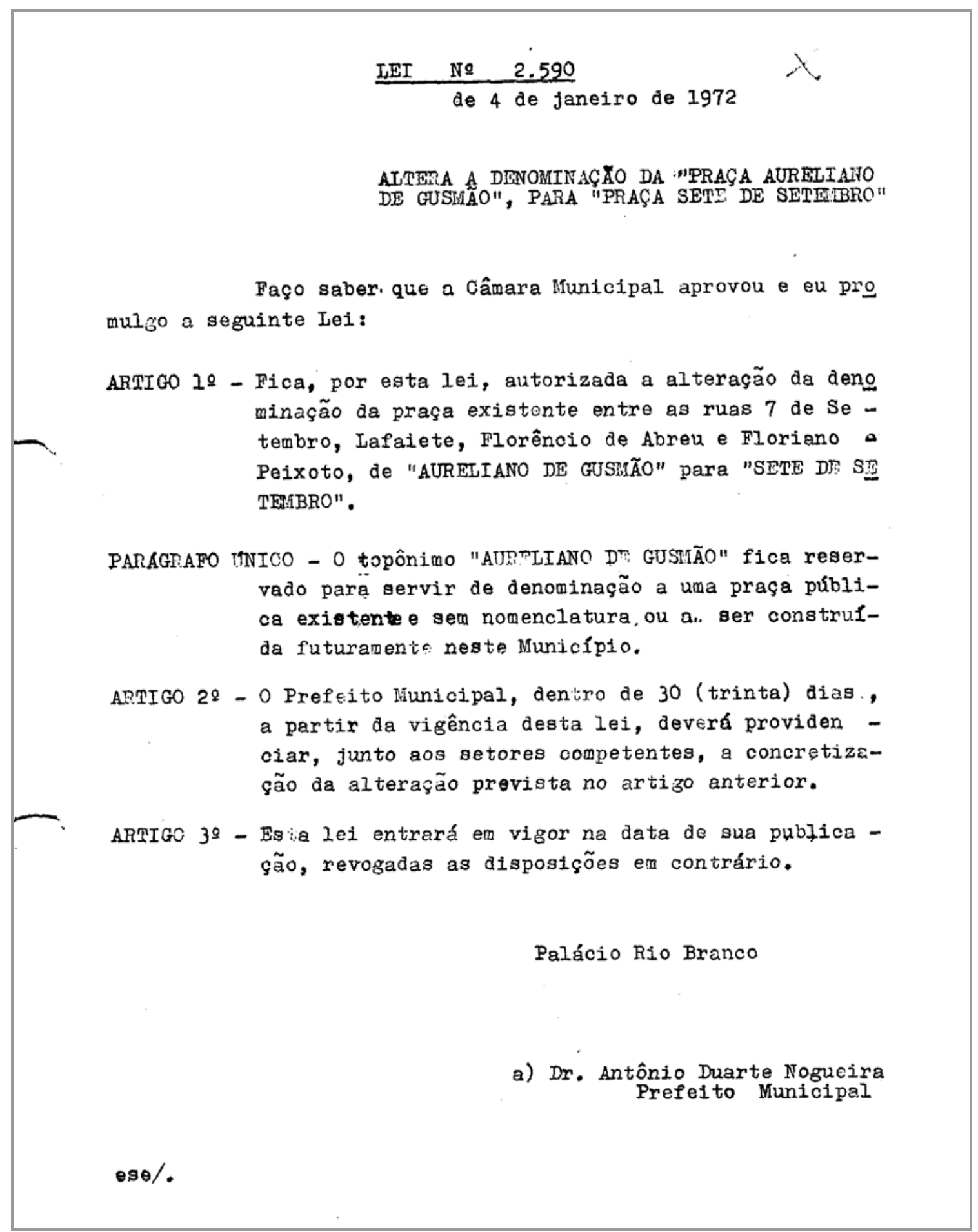

Figura 7. Documento que comprova a mudança na denominação da praça. Fonte: Arquivo Público e Histórico de Ribeirão Preto. 
Na sessão da Câmara de 13/07/1918 foi encaminhada uma representação de moradores da Praça Dr. Aureliano de Gusmão, solicitando ajardinamento daquele local (SANTOS, 1948). Este documento leva a acreditar que até esta data não haviam sido feitas melhorias naquele local.

As obras e os melhorias da Praça Sete de Setembro, foram introduzidos entre os anos de 1920 e 1926, durante o governo do prefeito João Rodrigues Guião (de 1920 a 1923 e de 1923 a 1926). Nos relatórios deste prefeito, apresentados à Câmara Municipal, há menção de que foram iniciadas as obras na Praça Aureliano de Gusmão (atual Praça Sete de Setembro).

A Praça Sete de Setembro foi ajardinada por volta dos anos 1925 e 1926 e permaneceu cercada de muro com tela de arame até próximo a década de 1940. Constam em relatos que esta praça era atraente desde seus primórdios, sendo ponto de encontro da população que habitava suas imediações. Era um espaço amplo e agradável onde as pessoas adentravam em busca de sombra, descanso, passeio e até mesmo para momentos entre casais de namorados (GOMES, 2005).

A presença de grades na praça é confirmada com a cópia do documento retirada no Arquivo Público e Histórico de Ribeirão Preto (Figura 8).

Durante a pesquisa de opinião realizada neste trabalho, muitos dos entrevistados disseram que havia um cemitério no local onde a praça se encontra. Com os documentos levantados no Arquivo Público e Histórico de Ribeirão Preto e de acordo com CIONE (1992) verifica-se que o cemitério e a Praça Aureliano de Gusmão eram próximos, porém em locais distintos. Muitos dos documentos conseguidos nos levantamentos não possuem datas, é o caso do mapa de localização da Praça (Figura 9).

CIONE (1992) relata que antes da Proclamação da República, quando eram fundadas as vilas, após as edificações das igrejas, os cemitérios eram feitos nos fundos dos referidos templos. Por isso ao ser construída a primitiva igreja que fora edificada onde se acha a majestosa fonte luminosa na Praça XV de Novembro, fora feito o pequeno cemitério nas proximidades da mesma. Com o crescimento da cidade, o cemitério tornou-se pequeno, então outro local foi escolhido, a atual Praça da Bandeira, onde se 
acha a Catedral Diocesana. Foi necessário um terceiro cemitério devido ao crescimento da cidade, nas imediações da Avenida Independência com a Rua Lafaiete. 


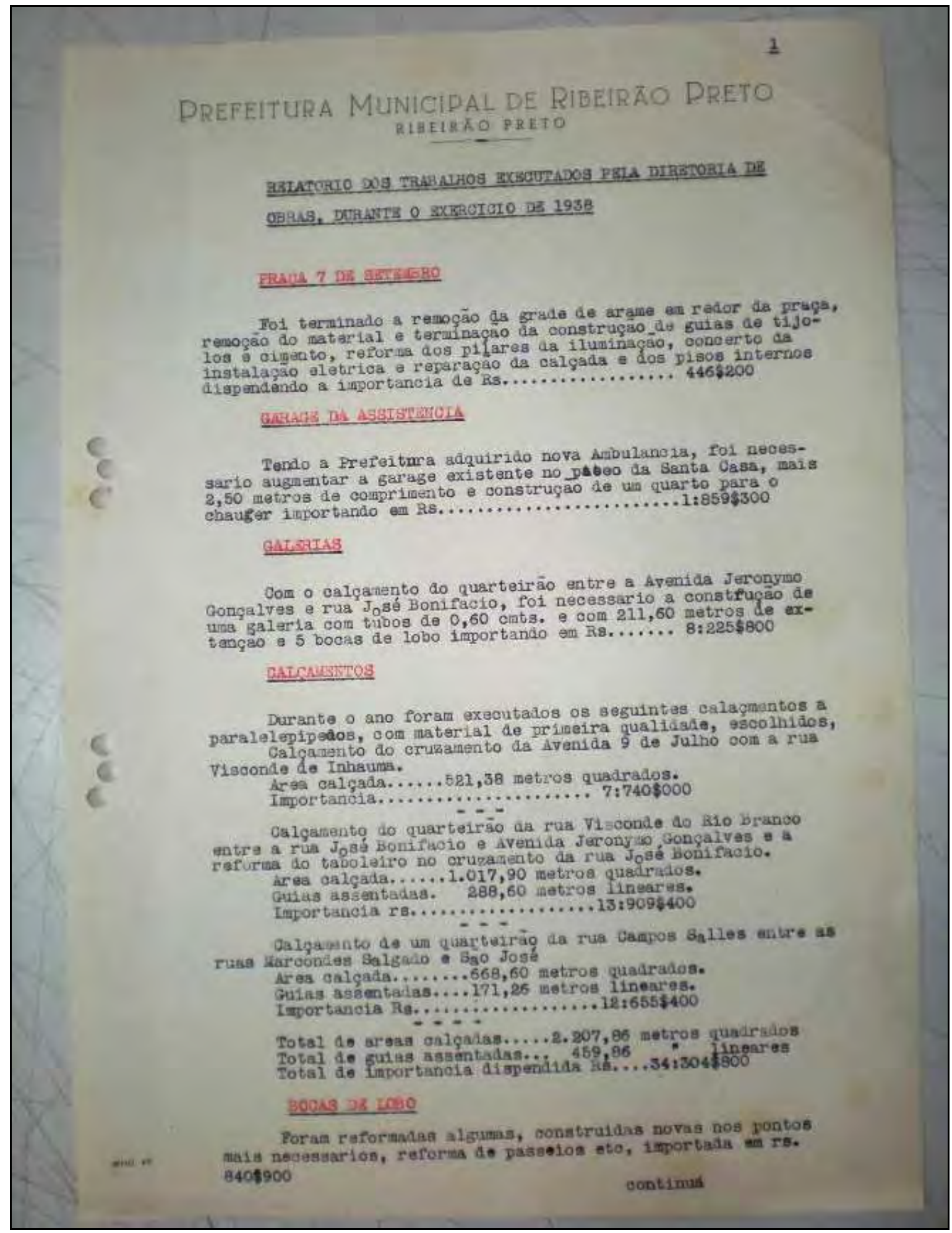

Figura 8. Documento que comprova a retirada das grades da Praça Sete de Setembro. Fonte: Arquivo Público e Histórico de Ribeirão Preto. 


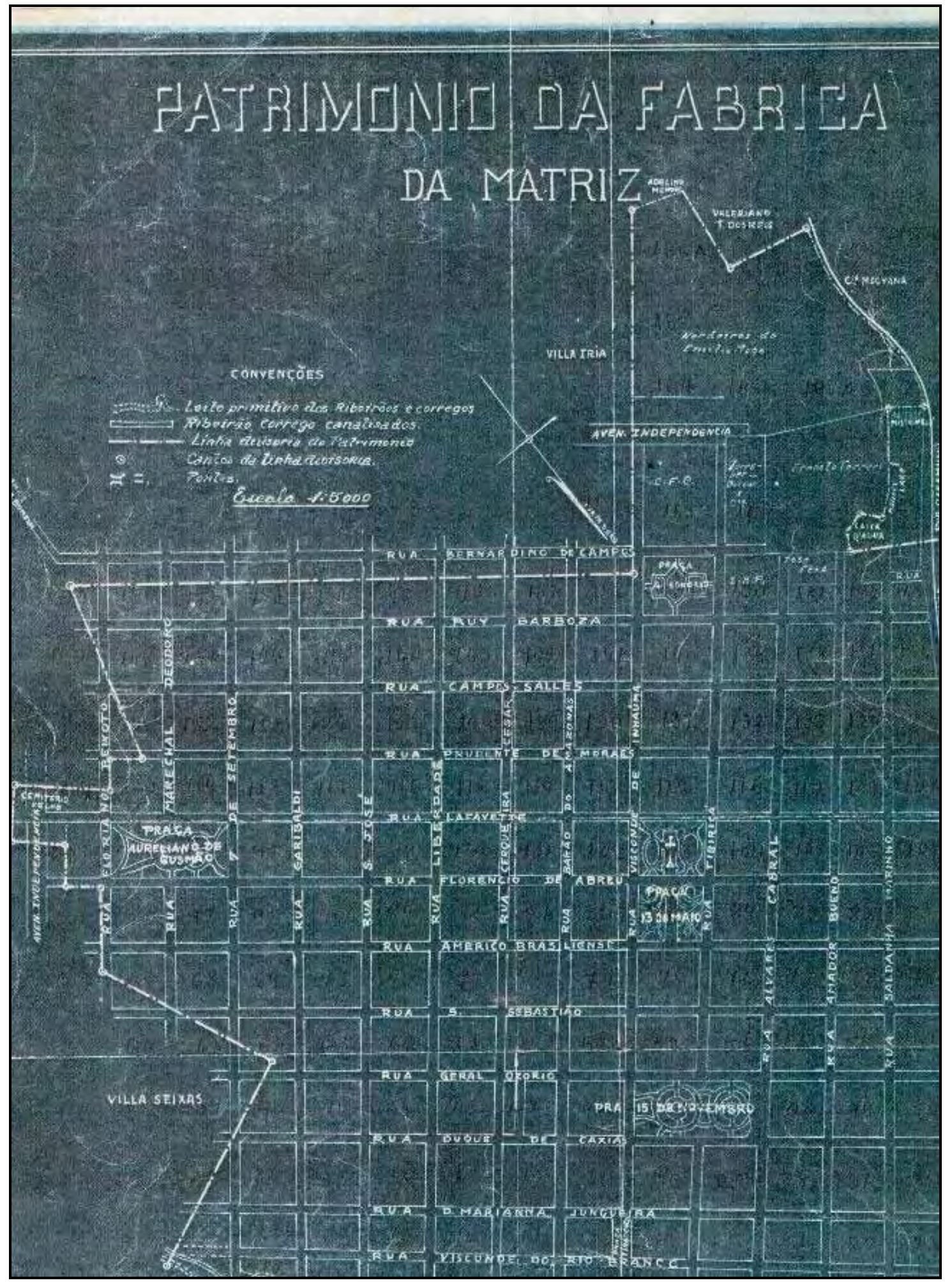

Figura 9. Localização da Praça Sete de Setembro. Fonte: Arquivo Público e Histórico de Ribeirão Preto. 
Foi encontrado no Arquivo Público e Histórico de Ribeirão Preto a planta da Praça Sete de Setembro, que embora não esteja datada, verifica-se atualmente o mesmo traçado antigo da praça (Figura 10a; 10b).

Durante o levantamento histórico da Praça Sete de Setembro, verificou-se a dificuldade de encontrar fotos antigas da praça, porém foi encontrado no Arquivo Público e Histórico de Ribeirão Preto um documento intitulado "Praças e monumentos que contam histórias" o qual continha uma foto da praça datada de 1956, de autor desconhecido (Figura 11).

Em 1996 o político e radialista Wilson Toni realizou por conta própria a construção de um lago na praça que logo foi retirado, pois a obra não foi autorizada pela Prefeitura (Figura 12). 
a.

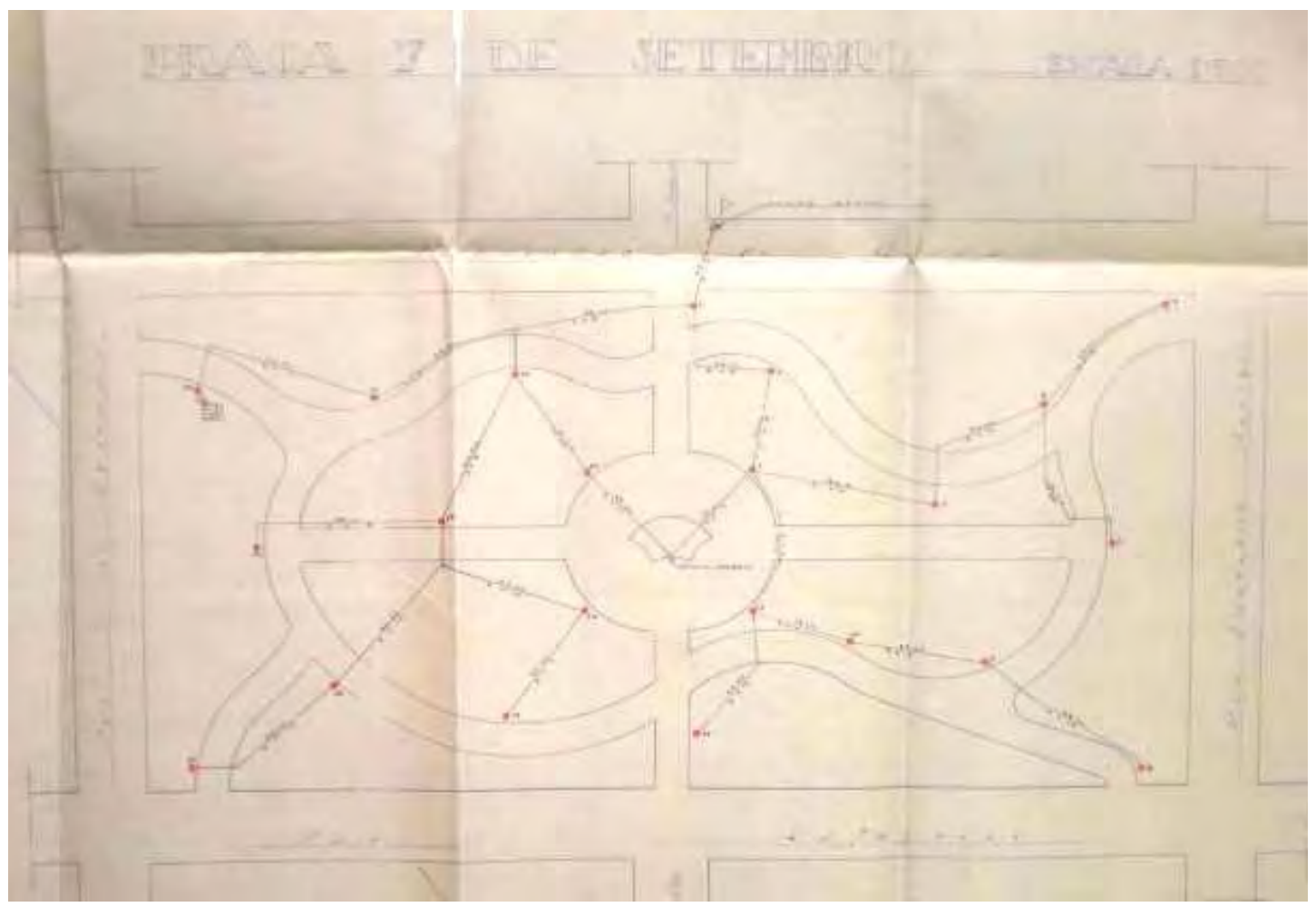

b.

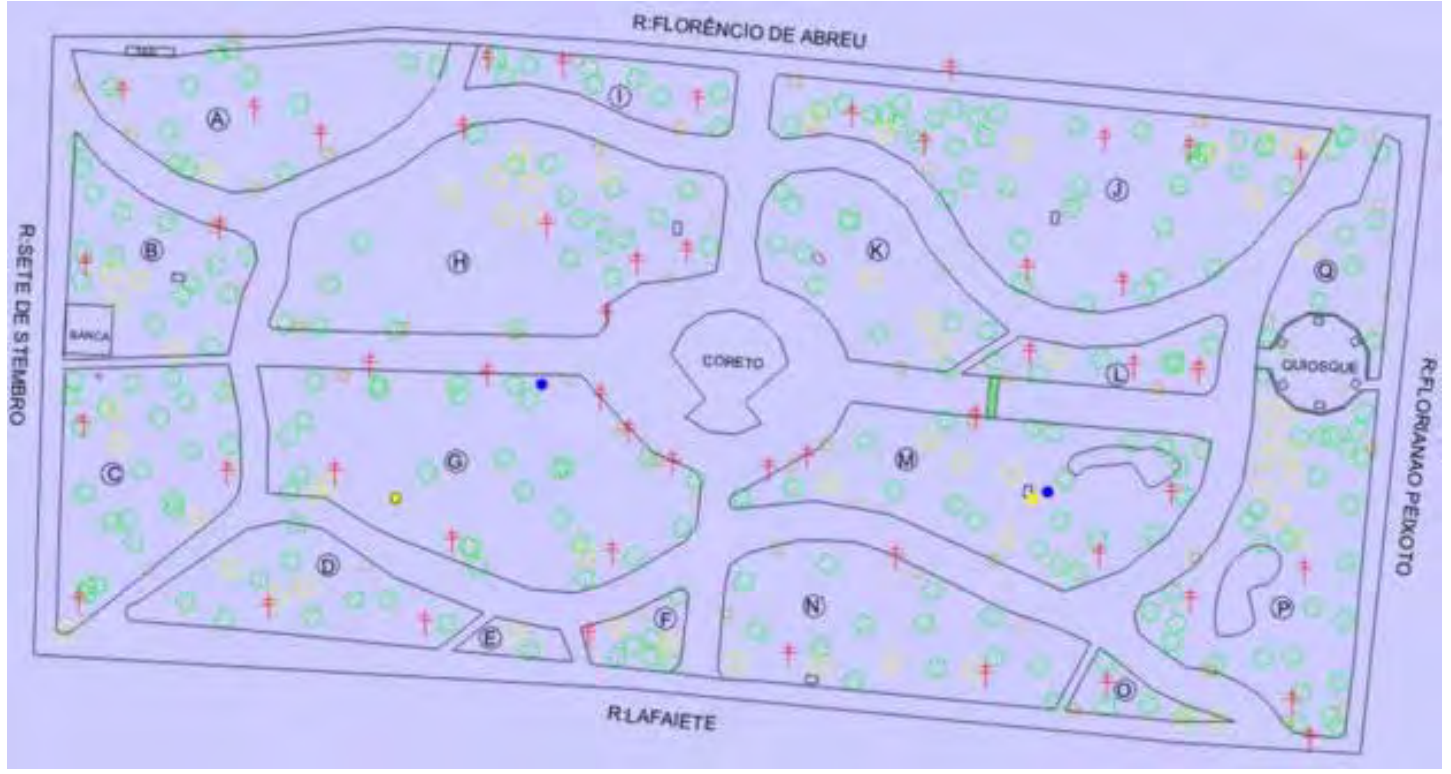

Figura 10. Levantamento planimétrico antigo (a), e recente realizado em outubro de 2009 (b). 


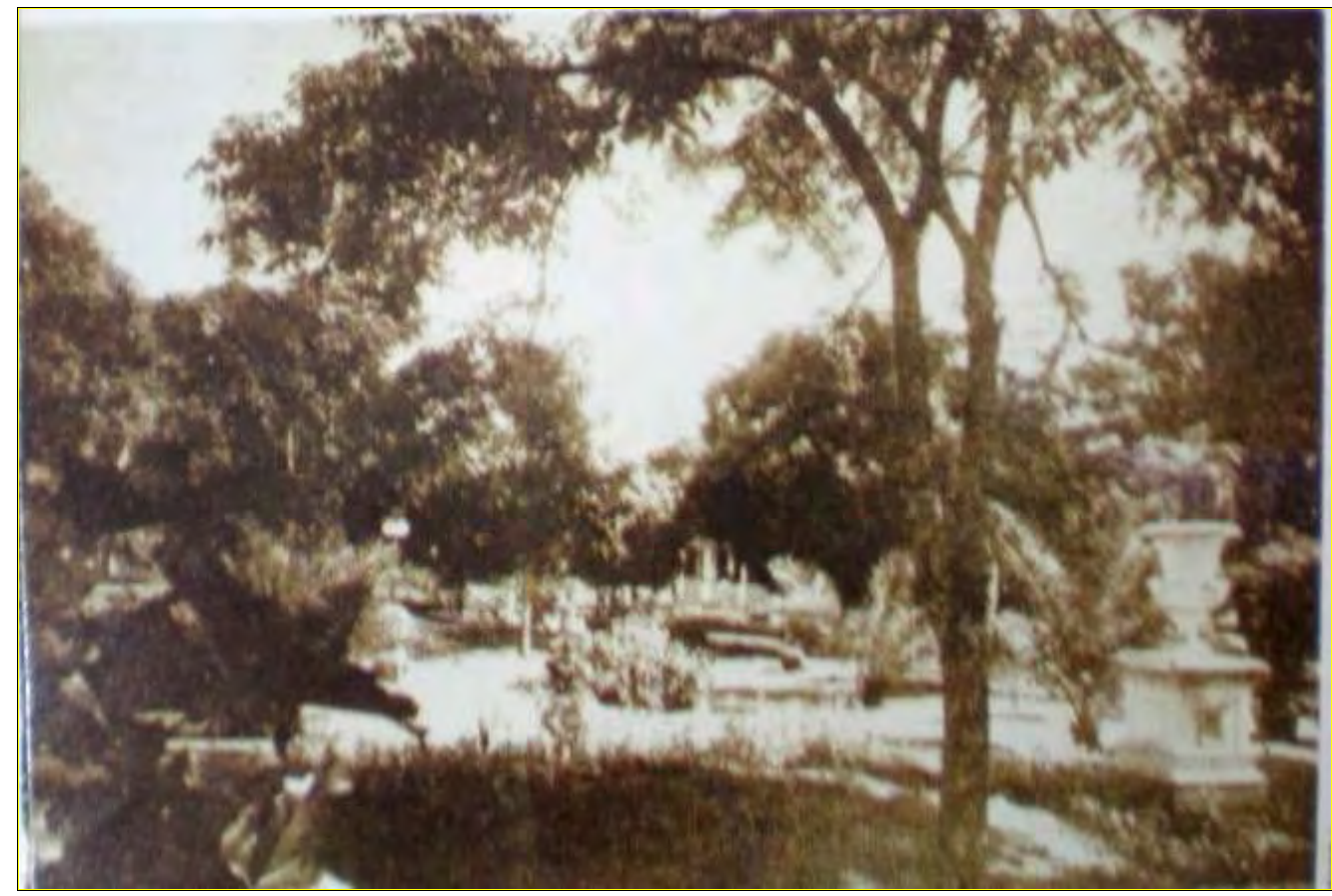

Figura 11. Foto da Praça Sete de Setembro de 1956, extraída do Folheto "Praças e monumento contam histórias".

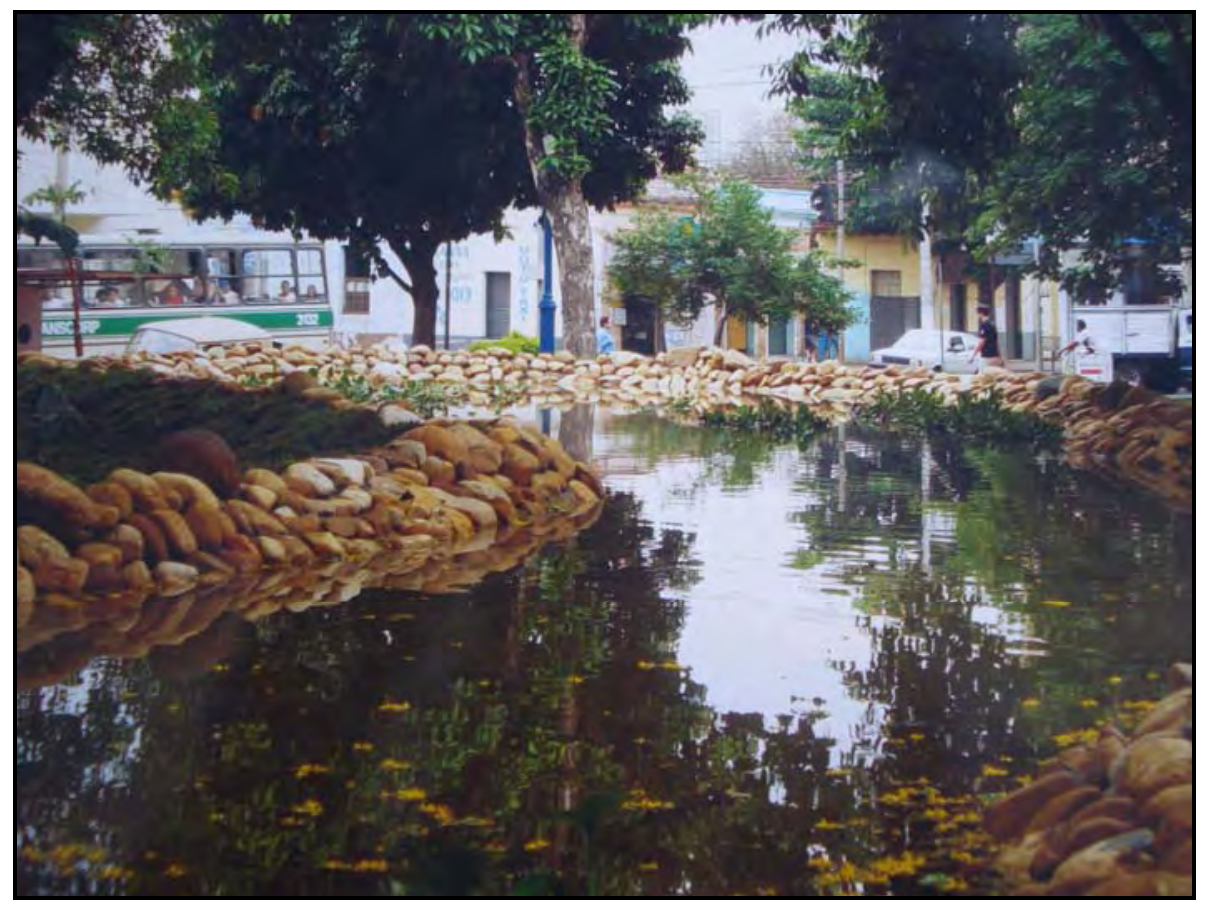

Figura 12. Lago da Praça Sete de Setembro, construído em 1996. Fonte: Ribeirão Vive o Verão. 
Foram encontrados muitos documentos sobre a Praça Sete de Setembro, no entanto vários deles não possuem datas. $O$ documento com a primeira nomeação do local (“Aureliano de Gusmão") não foi encontrado, verifica-se que boa parte da história da praça esteja perdida, mesmo com o esforço de historiadores da cidade.

A praça Sete de Setembro por muitas vezes foi reverenciada por ribeirãopretanos, ora com poemas, ora com obras de arte como a pintura apresentada na Figura 13.

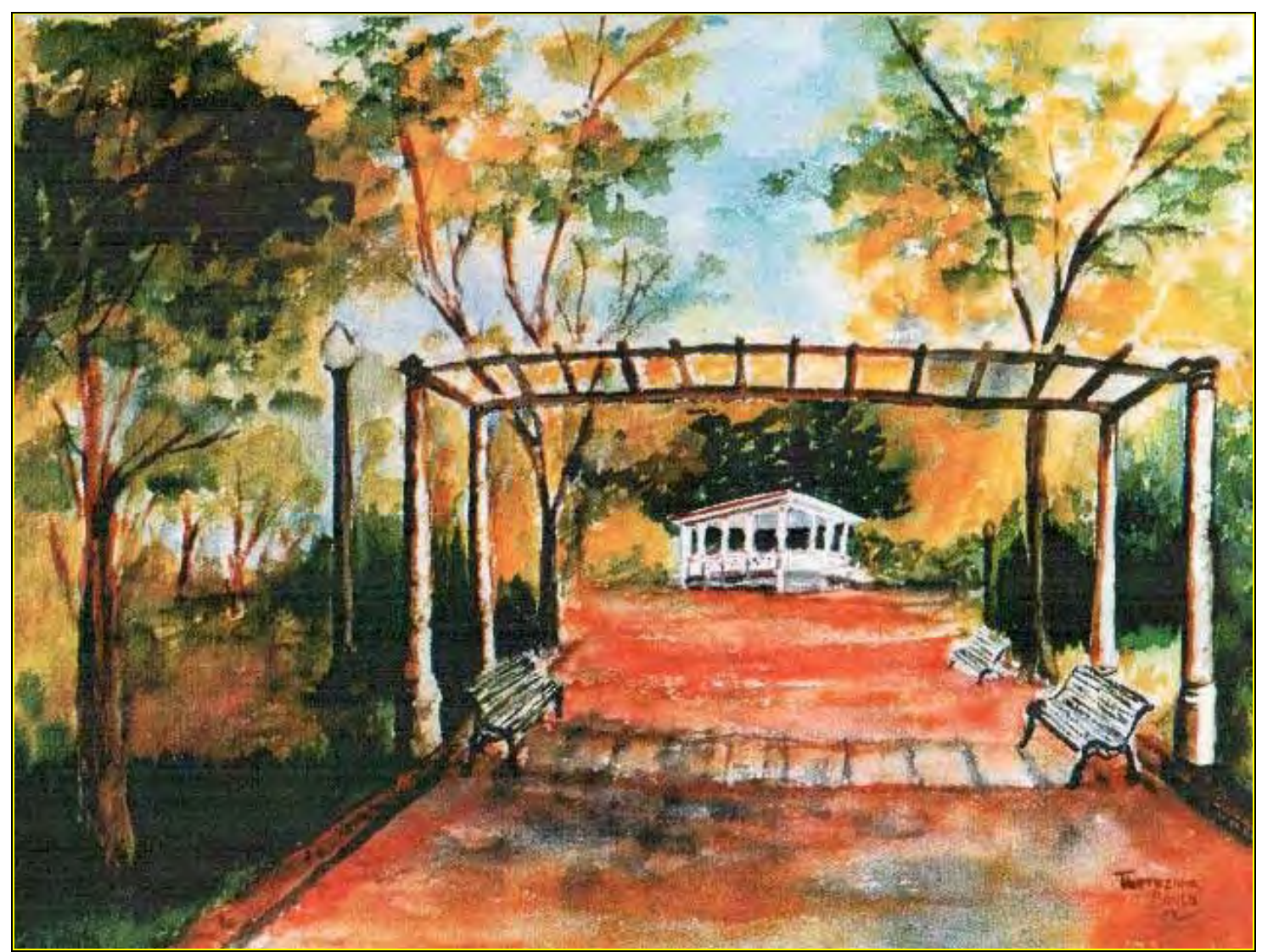

Figura 13. Pintura feita por Therezinha Araújo Filippi Bonfá. Livro: Ribeirão Arte. 
Praça 7 de Setembro

Área verde e espaçosa

Com muitas árvores frondosas

É a praça Sete de Setembro.

De manhã ou à tarde

Quando o sol brilha

Vem o povo caminhar

Fazer a sua trilha.

Um coreto antigo bem no centro

No seu coração

Recorda os velhos tempos

Os bons tempos de Ribeirão...

A banda ali tocava

E muita gente dançava.

Ignez A. Fonseca Bottura

\section{O VELHO CORETO}

Já vai distante minha infância, mas me lembro

Com saudades sutís e desmedido afeto

Da praça - o meu jardim de infância - do coreto,

Velho e imutável, lá do Sete de Setembro,

Do clarim do quartel, anunciando outro dia,

Do meu lar, do cachorro a correr desde cedo,

- Nada deixava em paz... e às vezes fazia medo...

De meu pequeno vulto, a brincar com alegria...

Foi-se o tempo e as manhãs, com meus irmãos na praça;

Mudou-se tudo em nôvo e moderno perfil,

Restando só de outrora algumas residências...

- Menos a minha e sim outra... nova e sem graça!

Porém está lá o coreto senhoril,

A falar-me tenaz de amplas reminiscências... 


\subsection{A praça e seus eventos artísticos e culturais}

A Praça Sete de Setembro é considerada uma das mais movimentadas da cidade, seus eventos são idealizados e incentivados pela Prefeitura Municipal de Ribeirão Preto.

Aos sábados pela manhã ocorre a feira de artesanato, incentivada pela Superintendência do Trabalho Artesanal nas Comunidades (SUTACO). Os artesãos participantes desta feira realizam um cadastro prévio na Casa da Cultura (Figura 14a). No final da feira, os participantes doam $10 \%$ de suas vendas a uma instituição de caridade. Este trabalho recebe o nome de Associação Projeto Arte Vida (APAV) (Figura 14bc).

Aos domingos, ocorre na praça exposição e venda de artes, esse evento recebe o nome de "Galeria a Céu Aberto", também está vinculado a Casa da Cultura, e os artistas participantes devem estar inscritos (Figura 15ab).

Os artistas relatam que no passado a organização do evento era feita por eles próprios e que era mais animado, atualmente a organização da exposição é realizada pela Casa da Cultura, que deixa a desejar na divulgação do trabalho.

Nas últimas sextas-feiras do mês ocorre o "chorinho" com a Banda Sexteto Colibri, também promovida pela Casa da Cultura. Durante a apresentação há pipoqueiros, vendedores de milho verde e balão. O evento é bastante familiar, e conta com a presença da polícia militar e da guarda municipal para a manutenção da segurança do local (Figura 16). 


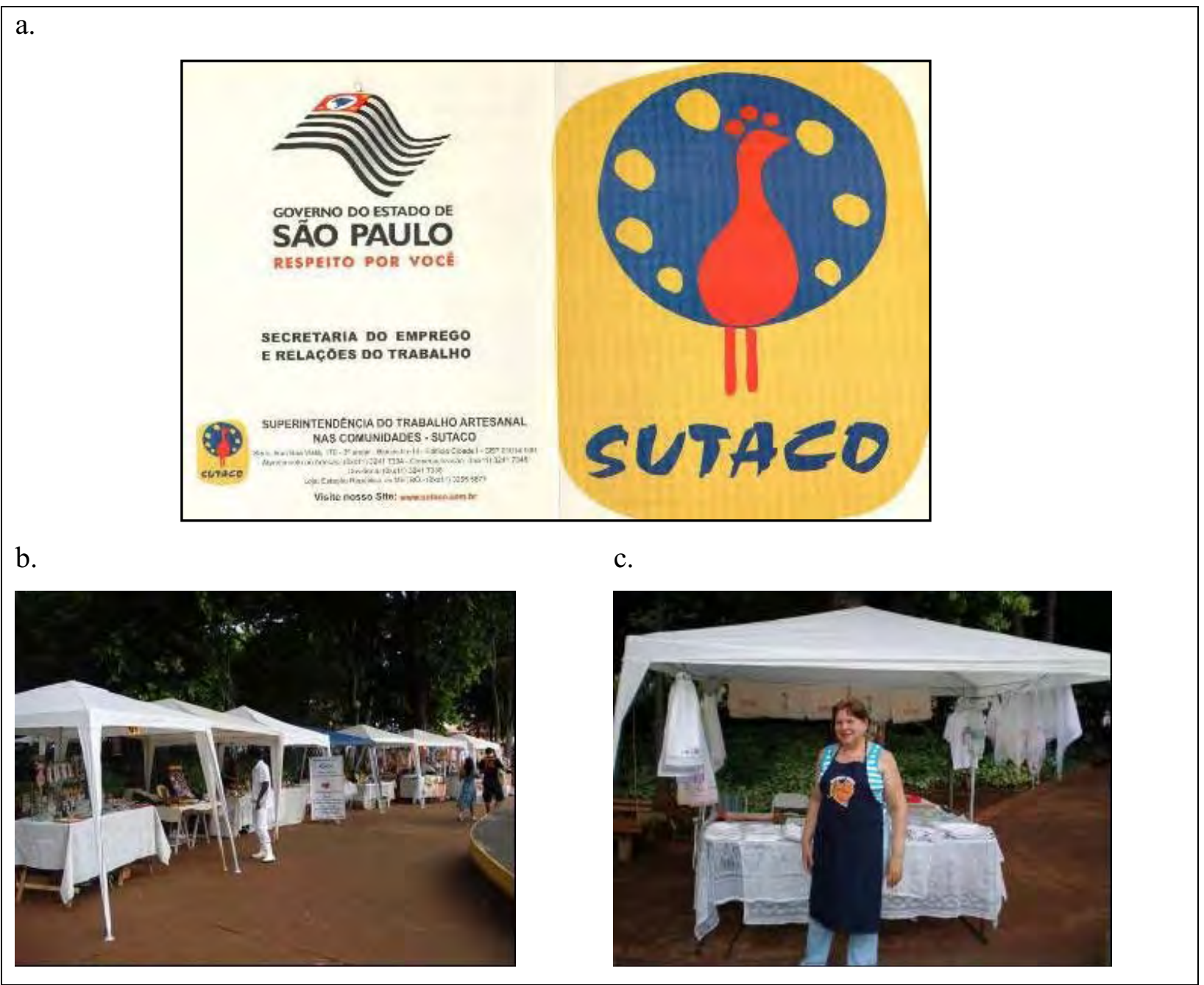

Figura 14. Folheto da Superintendência do Trabalho Artesanal das Comunidades (a), foto da feira de artesanato (b), foto de uma artesã (c). 

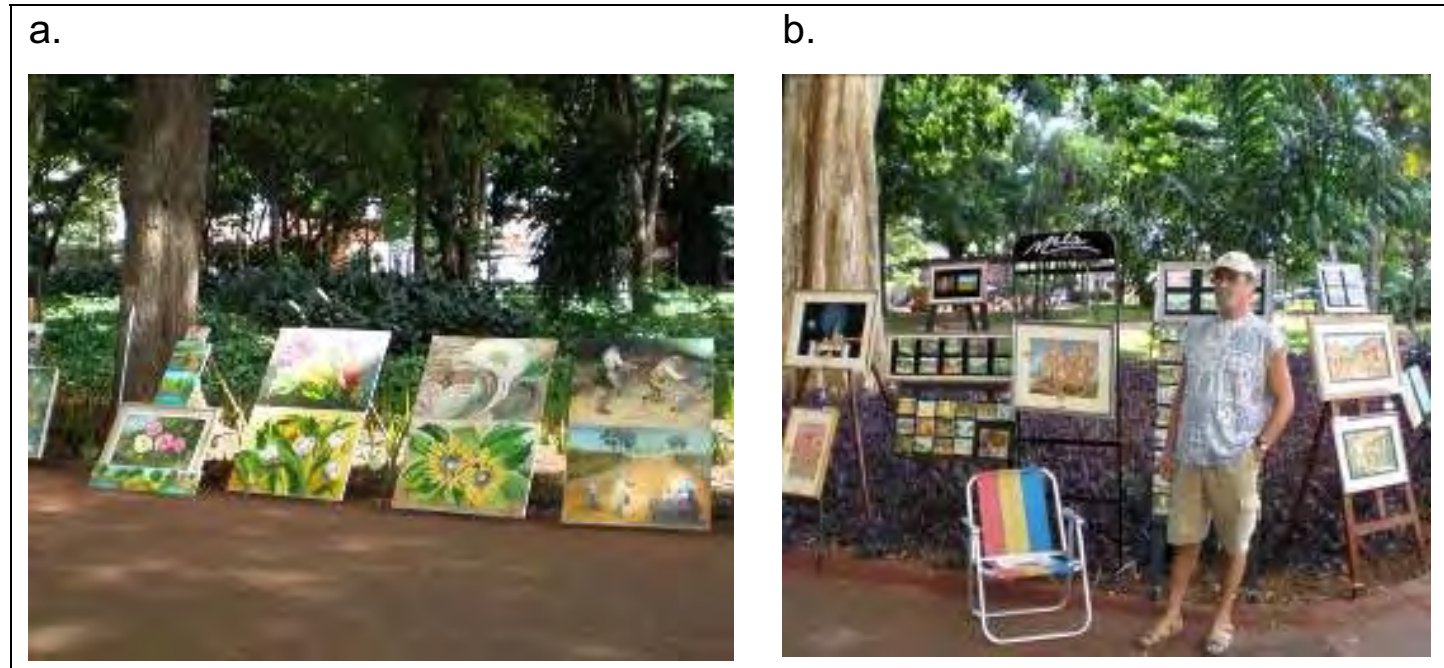

Figura 15. Galeria a Céu Aberto (a), expositor de pinturas e esculturas (b).

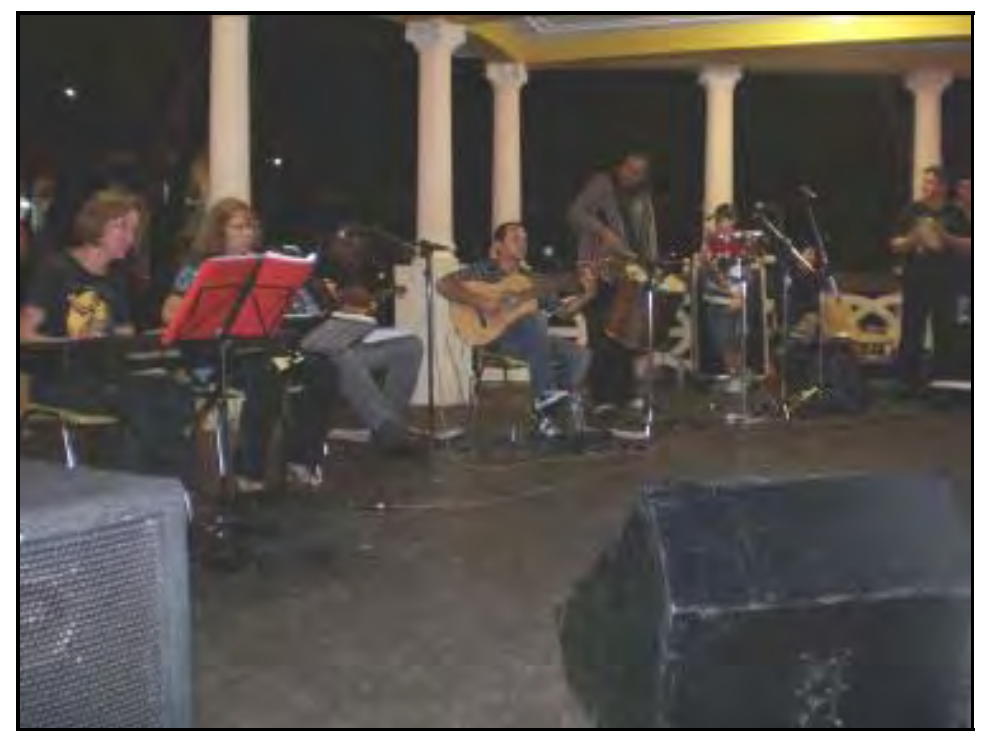

Figura 16. Apresentação do Sexteto Colibri no coreto da Praça Sete de Setembro.

Neste espaço público além dos eventos promovidos pela Prefeitura, ocorrem também manifestações populares como ensaios e apresentações de grupos amadores de teatro e dança, entre outros.

A constante freqüência dos usuários no local verifica-se que a Praça Sete de Setembro promove uma "vida" social bastante importante e diferenciada para a população, oferecendo lazer, convívio social e cultura para os seus freqüentadores. 


\subsection{Levantamento quali-quantitativo dos elementos arquitetônicos}

Na Figura 17 estão os resultados da avaliação dos elementos arquitetônicos encontrados na Praça Sete de Setembro.

\begin{tabular}{|l|c|c|}
\hline \multicolumn{1}{|c|}{ ESTRUTURAS AVALIADAS } & NOTA & AUSÊNCIA \\
\hline 01. Bancos & 3,0 & \\
02. Iluminação alta & 4,0 & \\
03. Iluminação baixa & 4,0 & \\
04. Lixeiras & 1,0 & \\
05. Sanitários & 4,0 & \\
06. Telefone público & & $\mathrm{X}$ \\
07. Bebedouros & 4,0 & \\
08. Piso & 4,0 & \\
09. Traçado dos caminhos & 3,5 & \\
10. Palco/coreto & 2,5 & \\
11. Pergolado & & $\mathrm{X}$ \\
12. Monumento & & $\mathrm{X}$ \\
13. Espelho d'água/chafariz & & $\mathrm{X}$ \\
14. Estacionamento & $\mathrm{X}$ \\
15. Ponto de ônibus & 4,0 & $\mathrm{X}$ \\
16. Ponto de táxi & & $\mathrm{X}$ \\
17. Quadra esportiva & & \\
18. Equipamentos para exercícios físicos & & \\
19. Estrutura para terceira idade & & \\
20. Parque infantil & & \\
21. Banca de revista & 4,0 & \\
22. Quiosque para alimentação e/ou similar & 3,0 & \\
23. Vegetação & 4,0 & \\
24. Paisagismo & 2,5 & \\
25. Localização & 4,0 & \\
26. Conservação/Limpeza & 2,5 & \\
27. Segurança & 1,0 & \\
28. Conforto ambiental & 4,0 & \\
Figu 17. Prosca & \\
\hline
\end{tabular}

Figura 17. Presença e nota dos elementos arquitetônicos encontrados na Praça Sete de Setembro, Ribeirão Preto, SP, 2010, adaptado de DE ANGELIS et al. (2004). 
Os elementos arquitetônicos encontrados na Praça Sete de Setembro e as características atuais são:

\subsubsection{Bancos}

Os bancos de uma praça devem ser confortáveis, duráveis, de fácil limpeza e aparência discreta. É interessante localizá-los de diferentes modos: ao sol e na sombra; isolados ou em grupos; voltados para dentro e para fora do espaço público (DEMATTÊ, 1999).

Há 55 bancos (Figura 18) em bom estado de conservação; são confortáveis, a estrutura é de ferro, o encosto e o assento são de madeira e combina com o traçado orgânico e sinuoso da praça. A distribuição espacial dos bancos situa-se ao longo do caminho pavimentado, tendo como limite as áreas ajardinadas, são encontrados tanto em locais de sombra como ao sol. Em alguns pontos da praça verifica-se um grande vazio do elemento em questão, alguns freqüentadores relataram que este vazio é devido a depedração dos mesmos e que não foram repostos. A quantidade de bancos existentes na praça é relatada pelos usuários como suficiente.

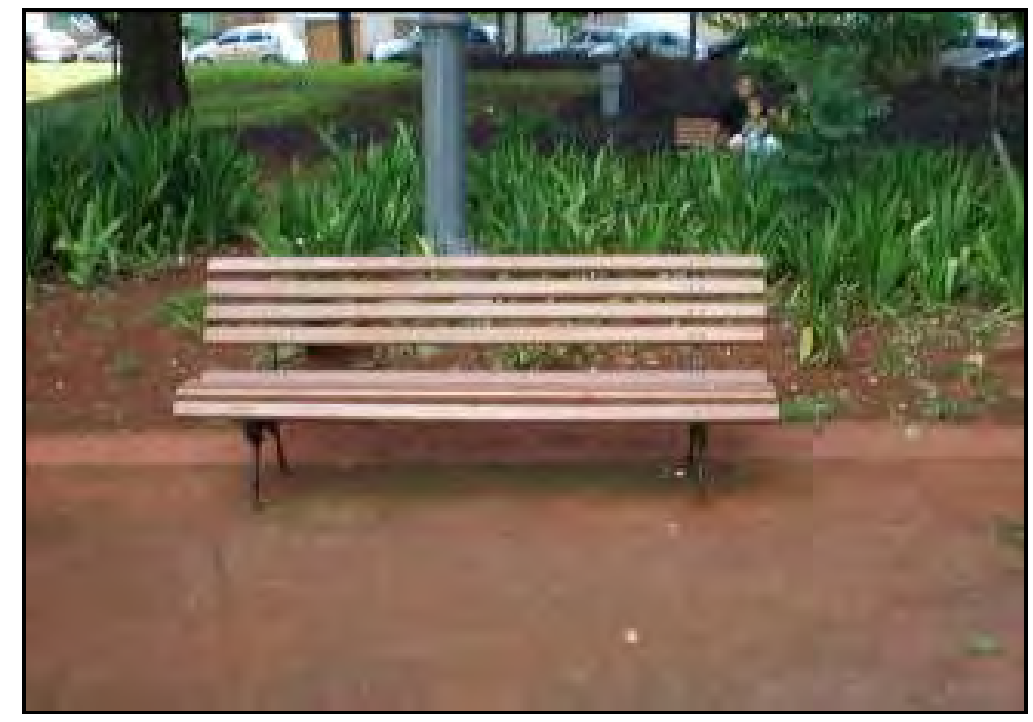

Figura 18. Aspecto do banco da Praça Sete de Setembro, Ribeirão Preto, SP. 2009. 


\subsubsection{Iluminação}

A iluminação de uma praça tem as funções de proporcionar segurança a seus usuários e de manter o valor visual e o conforto do ambiente noturno em níveis semelhantes aos proporcionados pela luz do sol. A distribuição das luminárias deve ser feita de modo a proporcionar aparência homogênea a toda massa de vegetação (DEMATTÊ, 1999).

O entorno da praça é iluminado com 18 postes de alta tensão (Figura 19a) e a parte central e os caminhos por 58 postes em estilo clássico (Figura 19b). Avaliou-se que a infra-estrutura presente proporciona uma iluminação adequada e que valoriza o projeto paisagístico

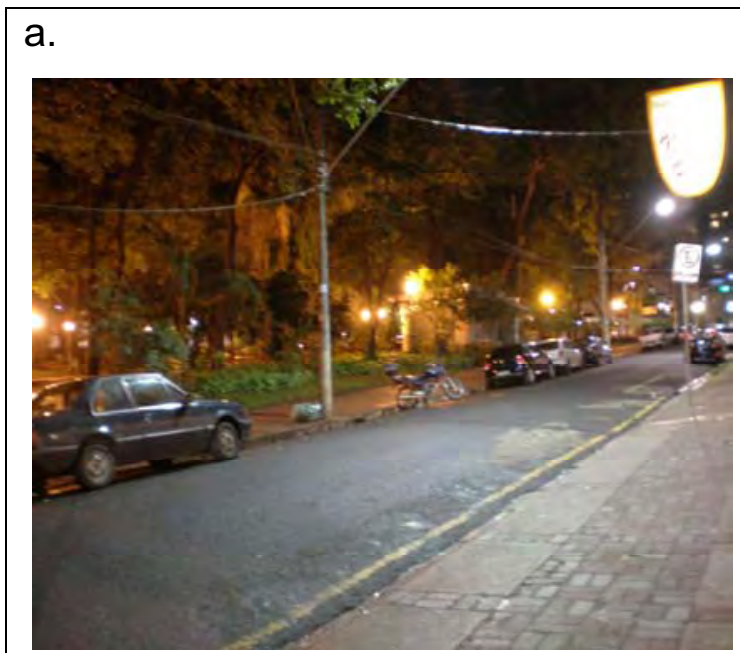

b.

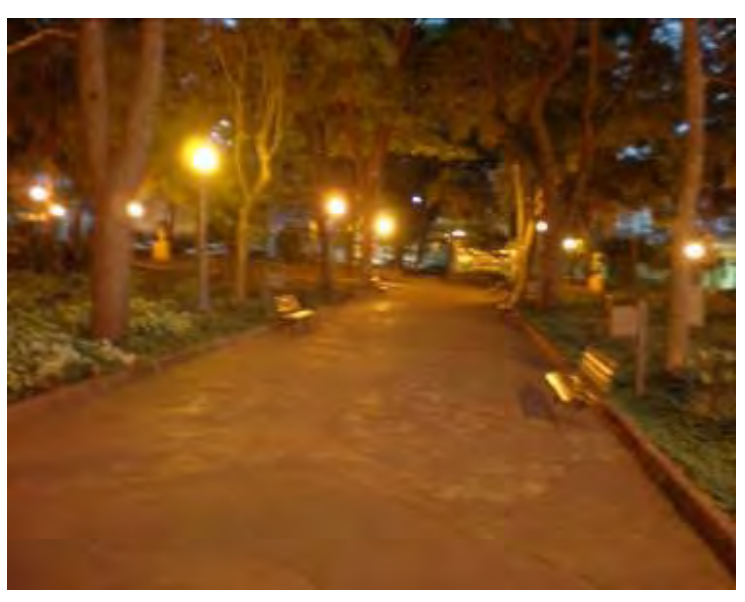

Figura 19. lluminação no entorno (a) e central da Praça Sete de Setembro (b).

\subsubsection{Lixeiras}

Há 65 lixeiras (Figura 20) de latão espalhadas pela praça, embora a quantidade de lixeiras seja alta não é o suficiente, pois seu volume é de apenas $0.024 \mathrm{~m}^{3}$, transbordando com freqüência os resíduos. A lixeiras eqüidistam em torno de $17 \mathrm{~m}$ uma da outra. Alguns usuários da praça queixaram dos locais em que as mesmas foram 
instaladas, a maior parte está ao lado dos bancos, causando desconforto devido ao odor de lixo.

DEMATTÉ (1999) relatou que as lixeiras devem ter aparência discreta e agradável, estando espalhadas a distâncias não maiores que 100 m umas das outras.

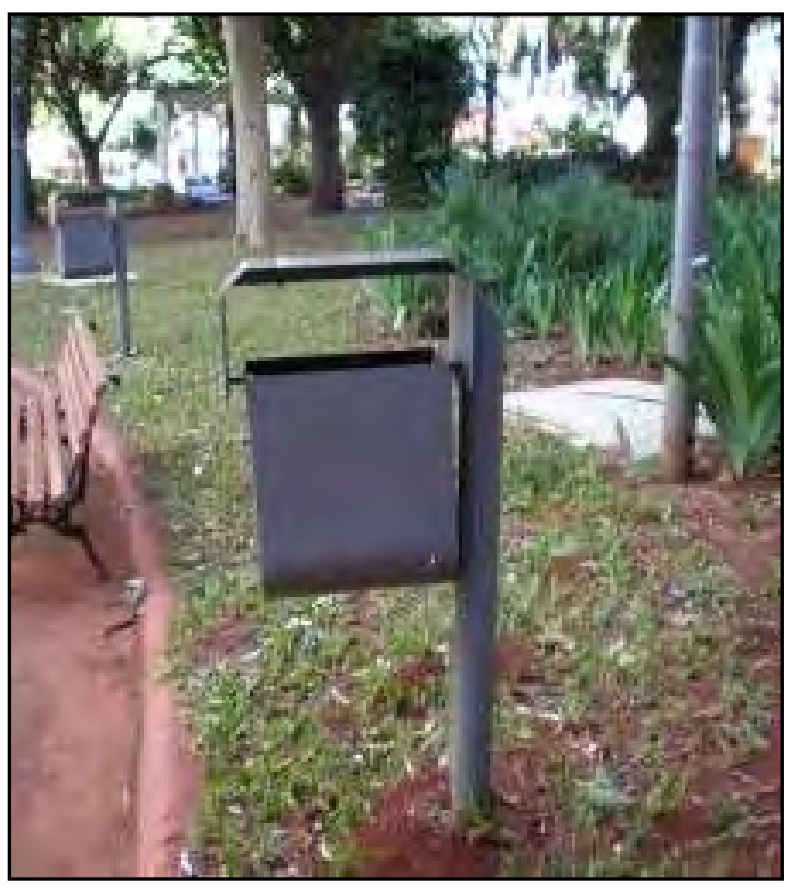

Figura 20. Lixeira da Praça Sete de Setembro.

\subsubsection{Telefone público}

Existem 11 telefones públicos (Figura 21) na praça, 9 deles estão protegidos por um quiosque que está localizado próximo a Rua Floriano Peixoto, 2 deles se encontram na esquina das ruas Sete de Setembro com a Lafaiete. Todos estão em bom estado de conservação e funcionamento. 


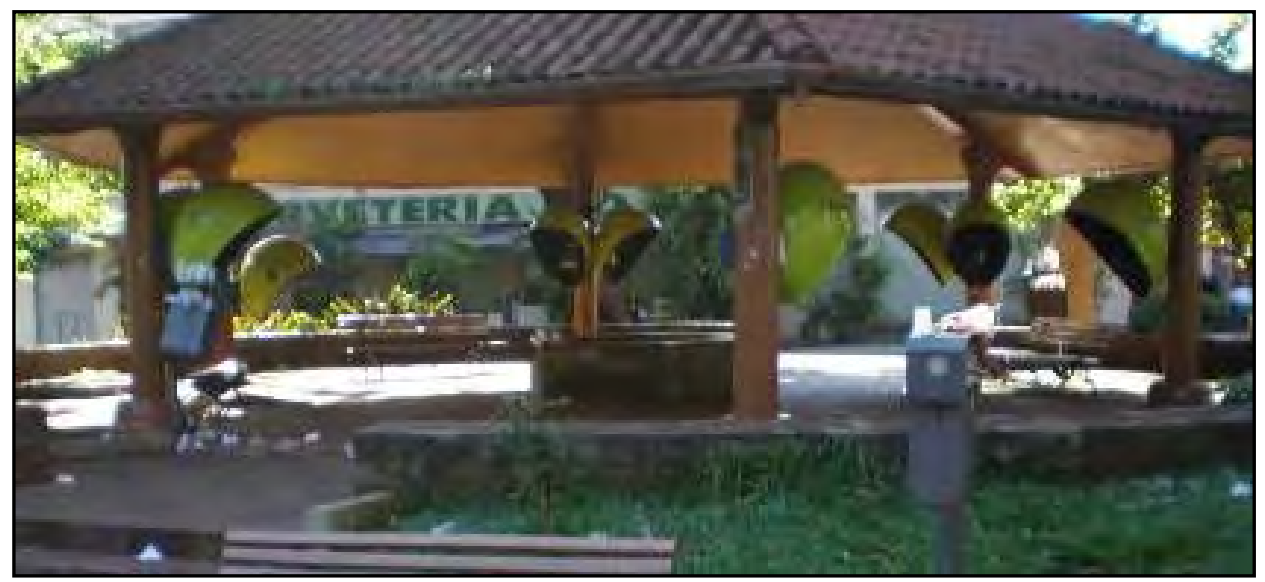

Figura 21. Telefones públicos protegidos por um quiosque.

\subsubsection{Piso}

O piso é pavimentado com cimento e pintado de coloração avermelhada (Figura 22). Encontra-se em bom estado de conservação, permitindo aos freqüentadores caminharem com segurança e tranqüilidade.

O cimentado é material de baixo custo, indicado para muros, muretas, degraus, bancos, piso, etc. Em pisos, o cimento pode ser colorido e receber texturas variadas (ABBUD, 2006).

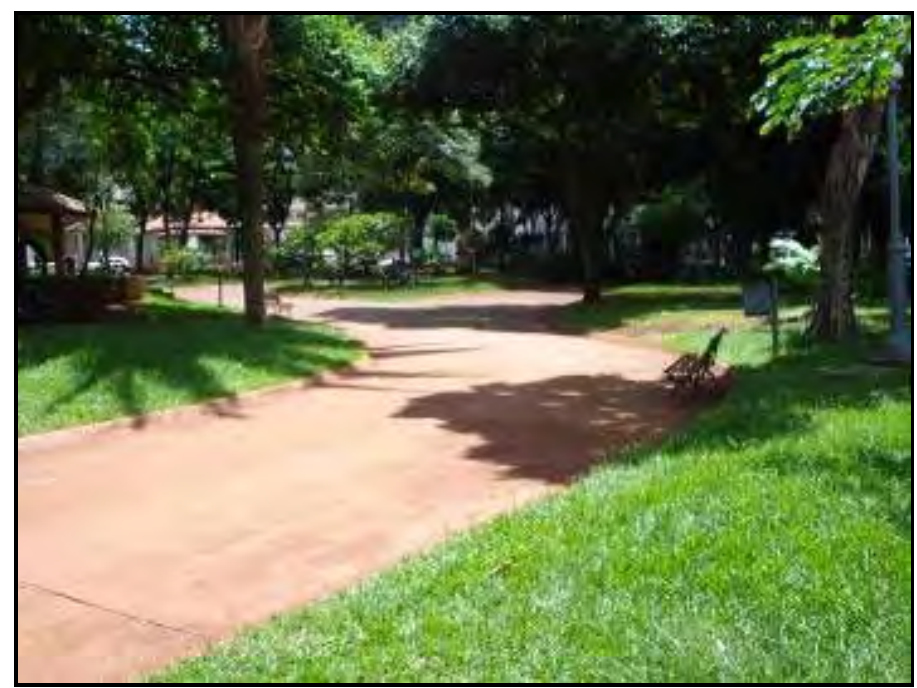

Figura 22. Aspecto do piso da praça. 


\subsubsection{Traçado dos caminhos}

A praça possui traçado orgânico e sinuoso e obedece a sua funcionalidade e segurança, visto que estão em boa conservação e permitem acesso a todos os pontos da praça.

Para DEMATTÊ (1999), os caminhos levemente ondulados propiciam integração maior com os valores paisagísticos, pois dão a impressão de naturalidade e visualmente são mais agradáveis.

\subsubsection{Palco/coreto}

Espaço amplo e bonito, feito de alvenaria, está em boa conservação. Está localizado no centro da praça (Figura 23).

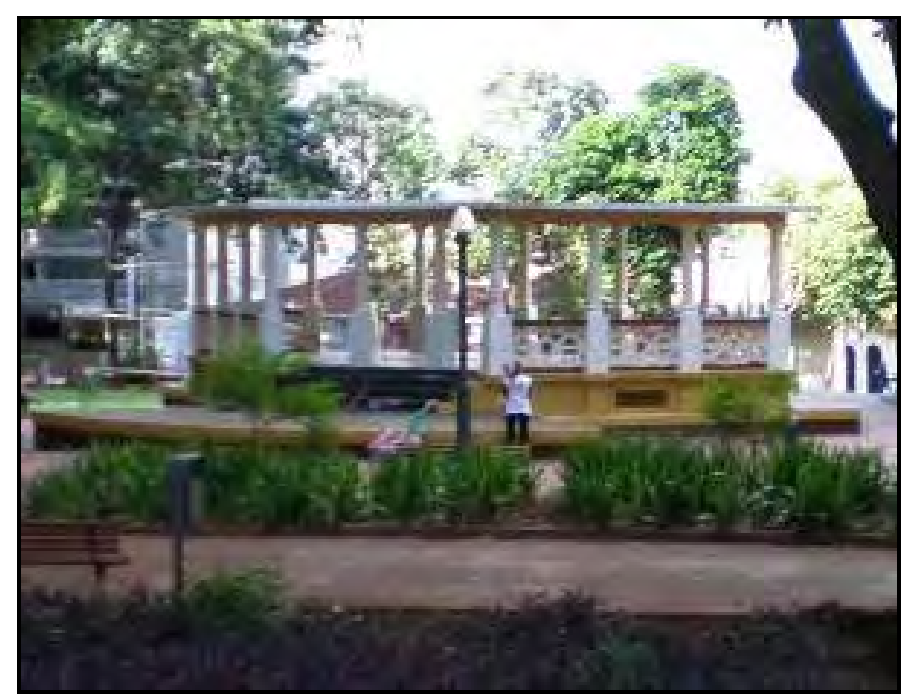

Figura 23. Aspecto do coreto.

\subsubsection{Escultura}

Existe uma única escultura na praça (Figura 24), que é notada por poucos, por ser bastante discreta. Ela é feita de madeira e está em bom estado de conservação. $\mathrm{Na}$ 
escultura tem a seguinte gravura: "Que a paz prevaleça no mundo". Esta frase foi gravada em 4 idiomas diferentes (português, inglês, japonês e francês).

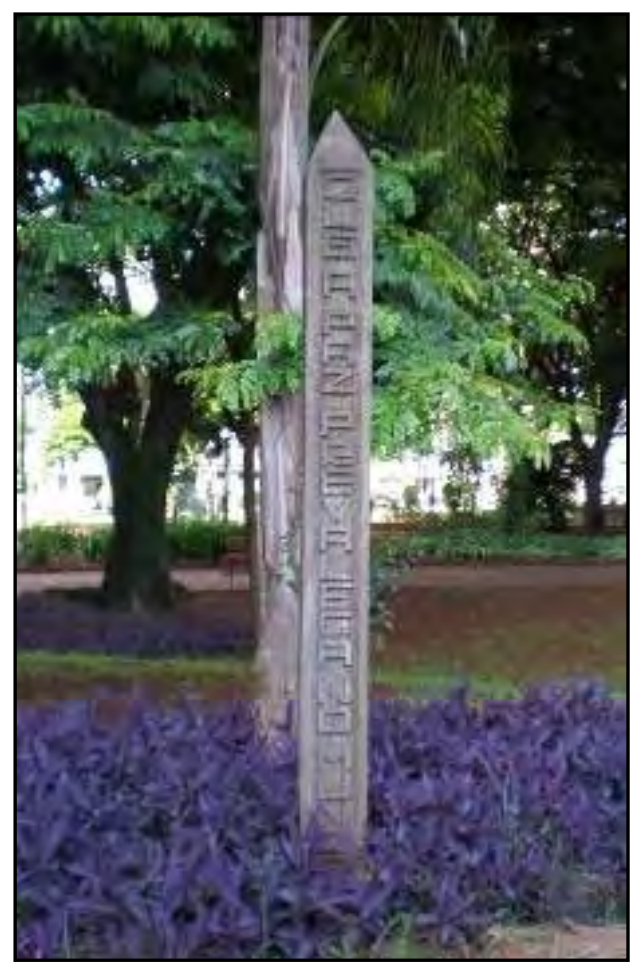

Figura 24. Escultura na praça.

\subsubsection{Pergolado}

Na praça pode-se verificar a presença de um pergolado feito de alvenaria, está em bom estado de conservação. 


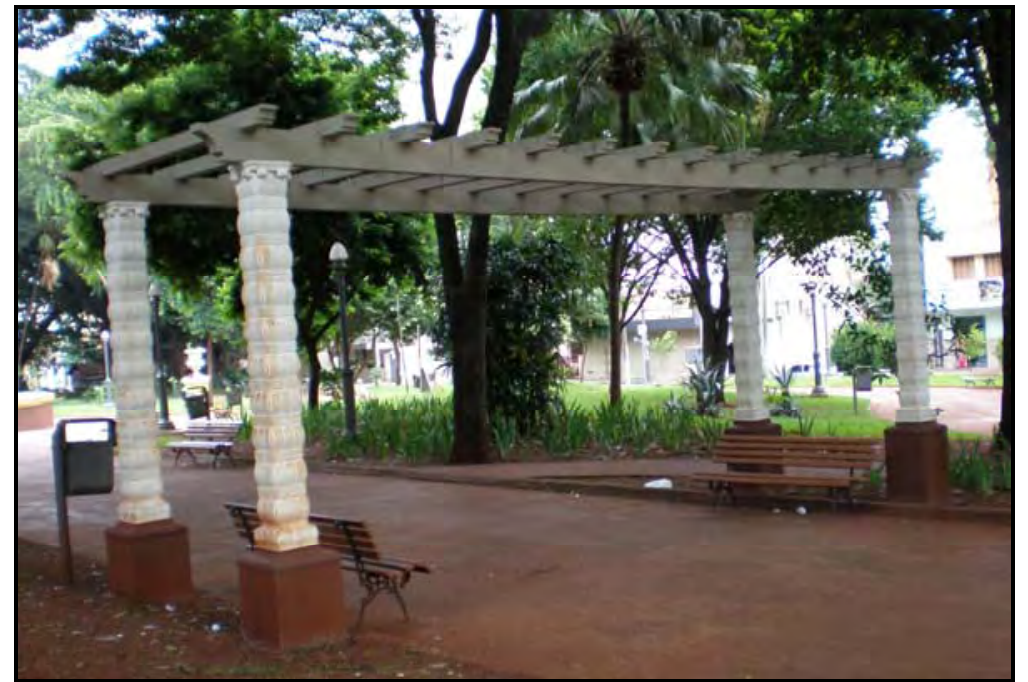

Figura 25. Aspectos do pergolado da praça.

\subsubsection{Estacionamento}

Não há estacionamento projetado para a praça (Figura 25), os carros são estacionados no entorno da praça sem que haja um recuo da rua. Verifica-se a presença de pessoas pedindo dinheiro em troca de "cuidarem" dos veículos, esta situação incomoda os freqüentadores do local.

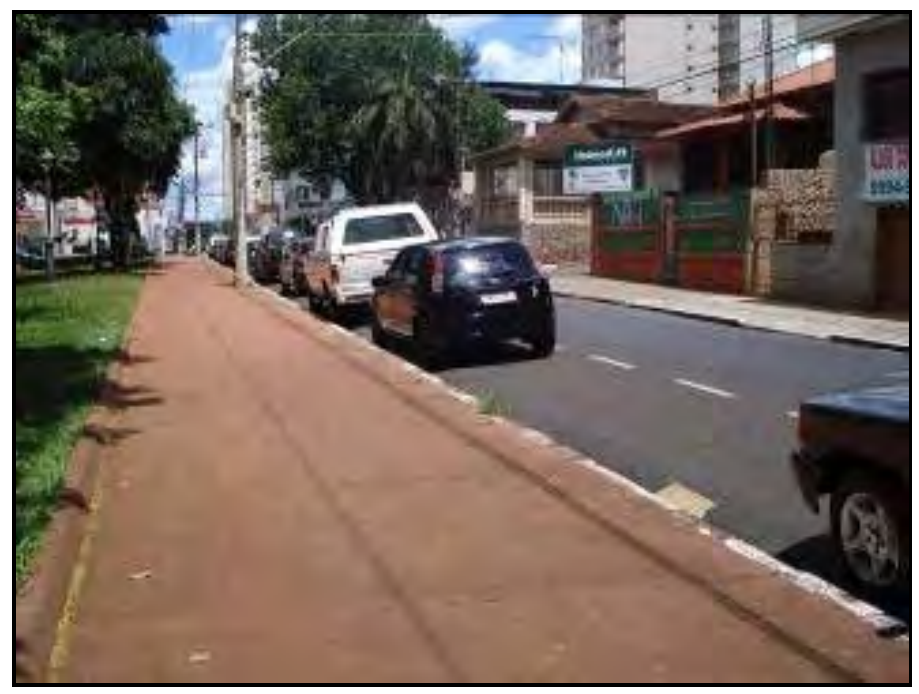

Figura 26. Aspecto do estacionamento da praça. 


\subsubsection{Ponto de ônibus e de táxi}

Existe um ponto de táxi (Figura 27) na praça localizado na Rua Florêncio de Abreu em que se verifica a presença de abrigo para os taxistas. Não há ponto para ônibus na praça.

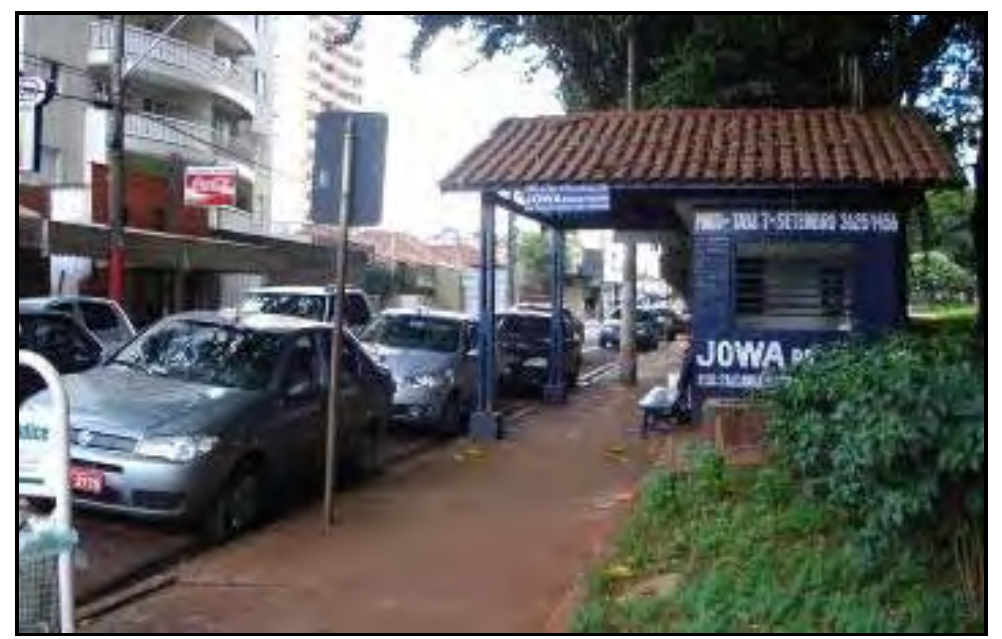

Figura 27. Ponto de táxi da Praça Sete de Setembro, Ribeirão Preto, SP, 2009.

\subsubsection{Banca de revista}

Há uma banca bastante tradicional na praça, que atende as necessidades dos usuários (Figura 28). 


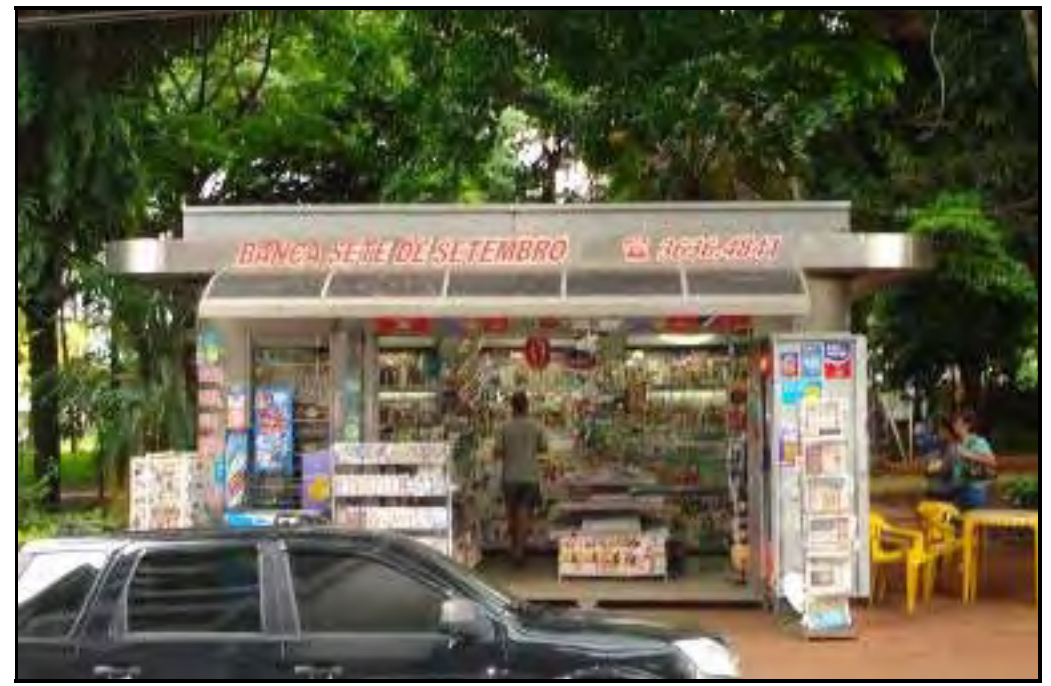

Figura 28. Banca de Revista da Praça Sete de Setembro, Ribeirão Preto, SP, 2009.

\subsubsection{Quiosque de alimentação}

Embora não combine com o estilo da praça, há um "carrinho de lanches" tipo "trailer" que fica localizado na esquina das ruas Floriano Peixoto com a Florêncio de Abreu (Figura 29). Nota-se que o proprietário do comércio em questão mantém o local livre de lixos, desta forma atrai uma clientela fiel.

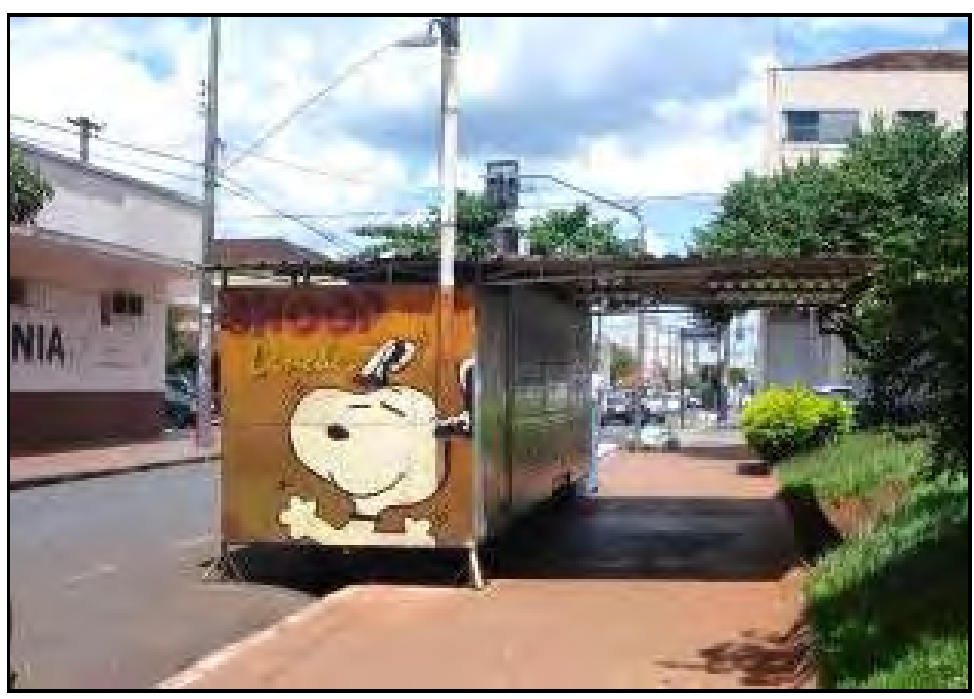

Figura 29. "Trailler" de lanches localizado na praça. 


\subsubsection{Vegetação/paisagismo}

A praça conta com uma vasta arborização, são árvores que promovem uma beleza natural excelente para o local. Quanto ao paisagismo, verifica-se que as forrações nunca são renovadas, além de terem pessoas despreparadas que plantam por conta própria, o que poderá futuramente causar conflitos com as espécies já implantadas no local (Figura 30).

A presença da vegetação tem uma função ecológica muito importante como a não impermeabilização do solo, uma fauna mais diversificada em áreas vegetadas, melhorias nos clima da cidade e na qualidade do ar, água e solo. A função estética diz respeito à diversificação da paisagem construída e o embelezamento da cidade (GUZZO, 1991).

Figura 30. Aspectos da forração da praça.

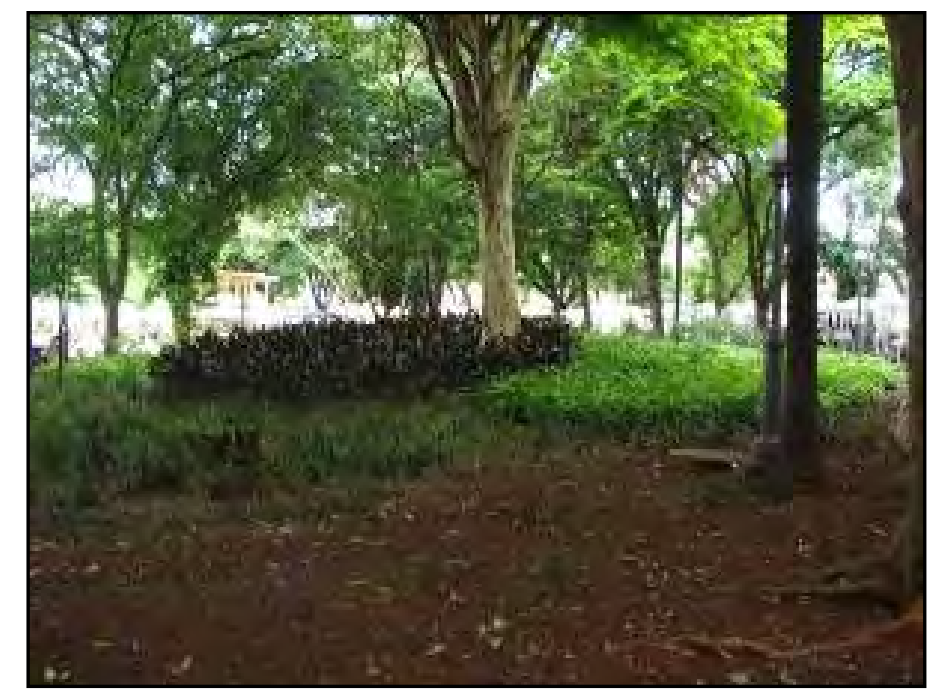

\subsubsection{Conservação/limpeza}

Embora haja pessoas capacitadas que realizam a limpeza e a conservação da praça diariamente, verifica-se muito lixo fora das lixeiras jogado pela população (Figura 31). 


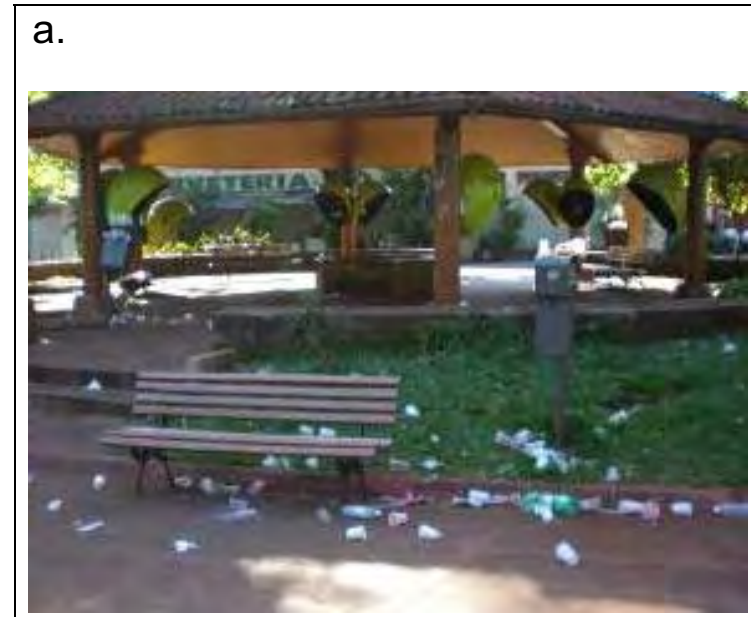

b.

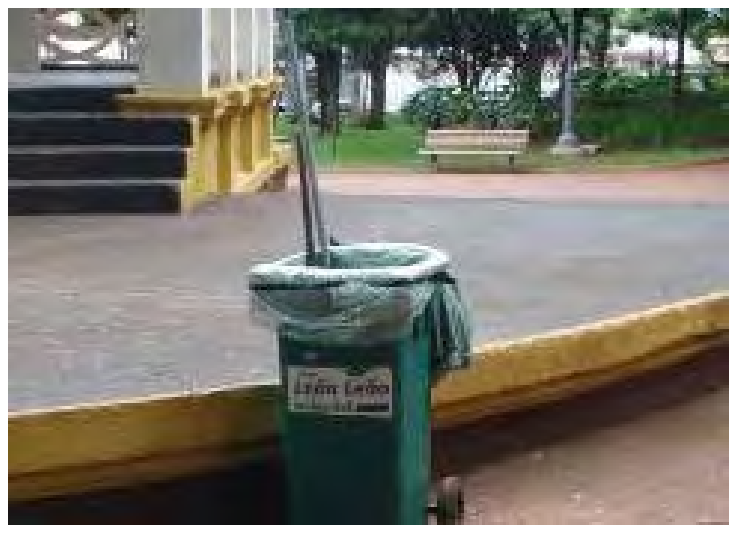

Figura 31. Aspectos da praça suja (a) e limpa (b).

\subsubsection{Segurança}

Precária, causando medo nas pessoas que por ali residem, embora muitos relatam que a praça em questão é a mais bem cuidada da cidade.

\subsubsection{Conforto ambiental}

É um local muito arborizado, promovendo grande conforto térmico e acústico.

\subsubsection{Rampa de acesso para deficientes físicos}

Embora este item não esteja na lista de DE ANGELIS et al., (2004), é de extrema importância levá-lo em consideração, para promover a inclusão social das pessoas com necessidades especiais. A praça possui rampas em todas as esquinas, as mesmas se encontram em bom estado de conservação e há um respeito muito grande pelos freqüentadores da praça em não impedir a passagem nestas rampas. 


\subsubsection{Outros aspectos}

Durante os levantamentos foram observados, e também, muito relatados pelos usuários da praça a falta de sanitários, bebedouros, espelho d'água, quadra esportiva e equipamentos para exercícios físicos e parque infantil.

A praça é deficiente em estruturas para promover a prática de exercícios físicos à população, tanto para a terceira idade como para o público infantil.

\subsection{Análise quali-quantitativa da arborização}

A praça possui árvores e palmeiras, a maior parte delas é de grande porte e proporciona sombra e bem estar àqueles que freqüentam o local. Foram catalogadas 86 espécies num total de 281 exemplares (Tabela 1). A figura abaixo mostra o dossel das espécies arbóreas no local (Figura 32).

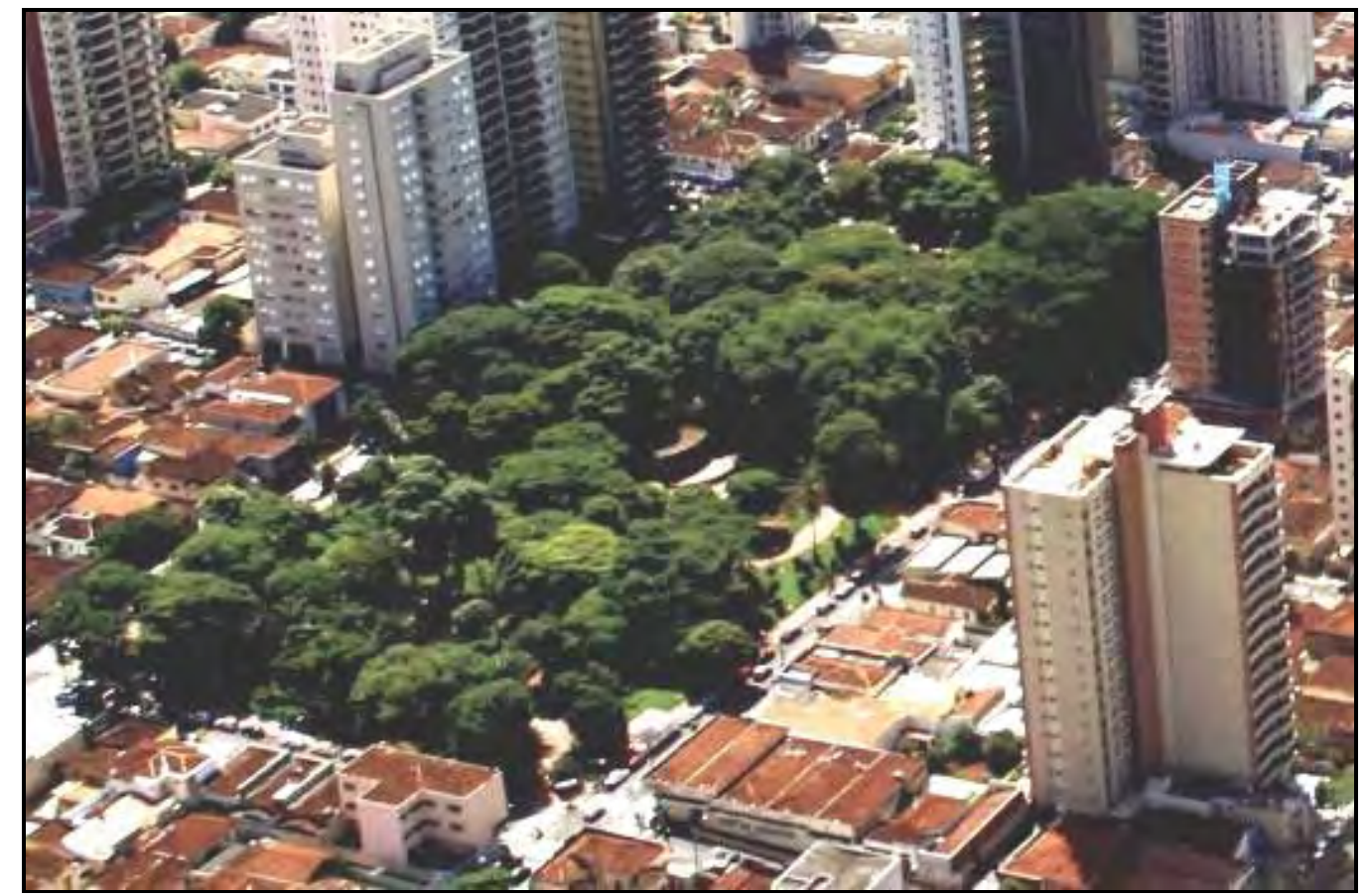

Figura 32. Aspectos da arborização da praça. Acervo particular de João Rossato. 
A variedade das espécies arbóreas proporciona um colorido ao longo do ano, com combinações de cores harmoniosas valorizando o paisagismo do local. A diversidade de árvores floríferas espalhadas pela praça promove diferentes pontos de interesse, quebrando a monotonia das caminhadas e incentivando a realização de novos percursos.

Para cada espécie de árvores, há épocas diferentes de florada como o ipê-roxo que floresce de junho a julho, os ipês amarelo e branco no mês de agosto, o jacarandá roxo de junho a setembro e a sapucaia entre setembro a outubro.

Existem muitas árvores frutíferas na praça, sendo um atrativo para macacos sagüis e diferentes espécies de pássaros. (Figura 33).

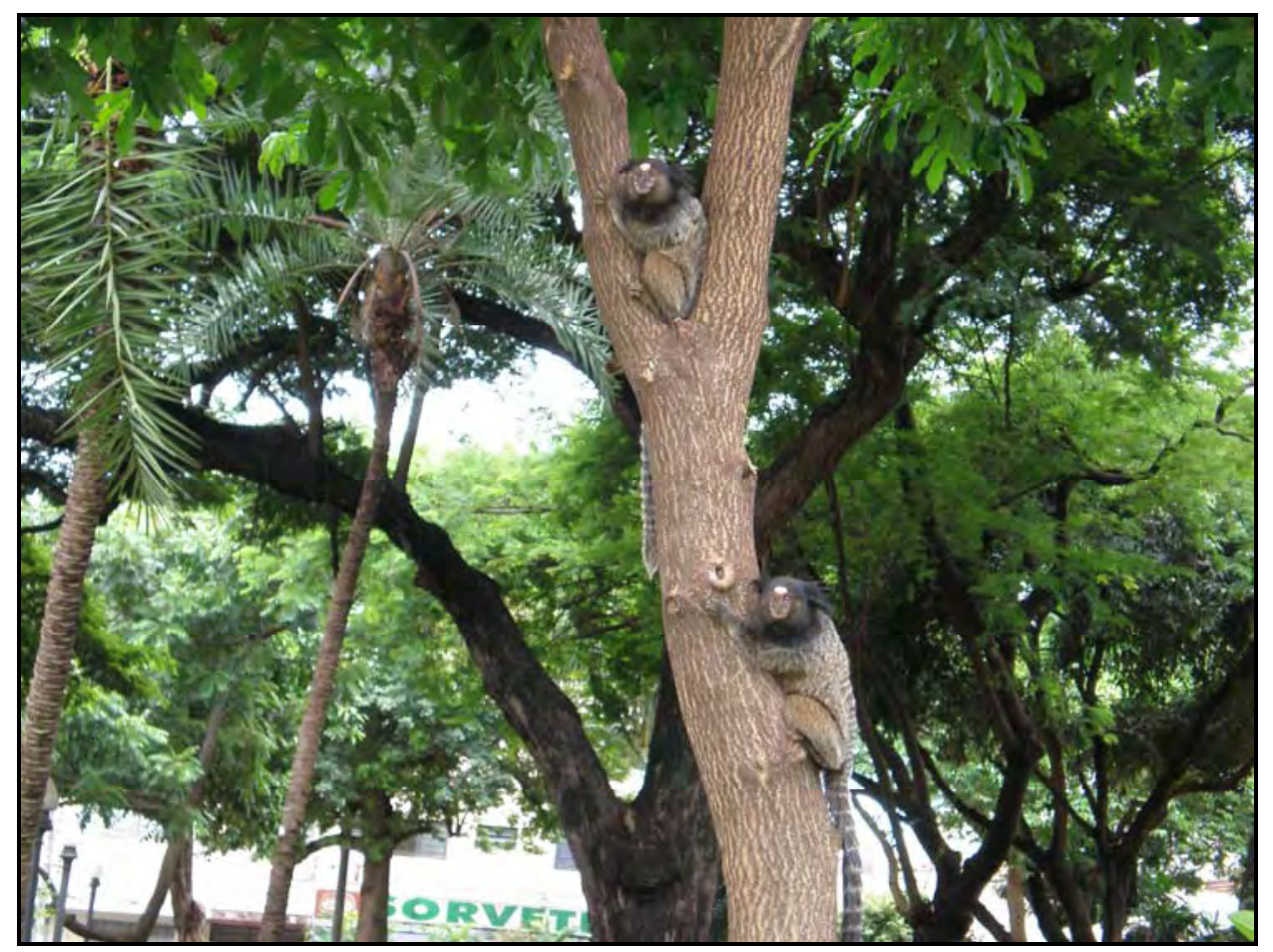

Figura 33. Macacos sagüis na Praça Sete de Setembro, Ribeirão Preto, SP. 
Segundo RODERJAN e BARDDAL (1998), a paisagem rica e diversificada de um espaço destinado à grande circulação de pessoas é garantia de um ambiente onde há benefícios ecológicos, sociais e econômicos. 
Tabela 1. Levantamento das espécies arbóreas da Praça Sete de Setembro em Ribeirão Preto, UNESP, Jaboticabal, SP, 2010.

\begin{tabular}{|c|c|c|c|c|}
\hline NOME CIENTÍFICO & NOME COMUM & FAMÍLIA & NI & FR \% \\
\hline Albizia hasslerii & Farinha-seca & Fabaceae & 3 & 1,06 \\
\hline Anacardium occidentale & Caju & Anacardiaceae & 2 & 0,71 \\
\hline Anona muricata & Graviola & Annonaceae & 2 & 0,71 \\
\hline Archontophoenix alexandrae & Palmeira-real-da-austrália & Arecaceae & 3 & 1,06 \\
\hline Artocarpus heterophyllus & Jaca & Moraceae & 2 & 0,71 \\
\hline Aspidosperma cylindrocarpon & Peroba-poca & Apocynaceae & 1 & 0,35 \\
\hline Aspidosperma pyrifolium & Peroba & Apocynaceae & 1 & 0,35 \\
\hline Aspidosperma polyneuron & Peroba-rosa & Apocynaceae & 13 & 4,63 \\
\hline Averrhoa carambola & Carambola & Oxalidaceae & 1 & 0,35 \\
\hline Bactris gasipaes & Pupunha & Arecaceae & 5 & 0,71 \\
\hline Bixa orelana & Urucum & Bixaceae & 1 & 0,37 \\
\hline Brunfelsia grandiflora & Manacá & Solanaceae & 6 & 2,13 \\
\hline Caesalpinia echinata & Pau-brasil & Fabaceae & 6 & 2,13 \\
\hline Caesalpinia férrea & Pau-ferro & Fabaceae & 3 & 1,10 \\
\hline Caesalpinia peltophoroides & Sibipiruna & Fabaceae & 18 & 6,40 \\
\hline Cariniana estrellensis & Jequitibá-branco & Lecythidaceae & 2 & 0,71 \\
\hline Cariniana legalis & Jequitibá-rosa & Lecythidaceae & 1 & 0,35 \\
\hline Cariniana rubra & Jequitibá-vermelho & Lecythidaceae & 1 & 0,35 \\
\hline Cássia excelsa & Cassia-excelsa & Fabaceae & 1 & 0,35 \\
\hline Cássia fistula & Chuva-de-ouro & Fabaceae & 3 & 1,06 \\
\hline Cedrela fissilis & Cedro-rosa & Meliaceae & 1 & 0,35 \\
\hline Ceiba boliviana & Paineira-rosa & Bombacaceae & 2 & 0,71 \\
\hline Centrolobium microchaete & Araribá & Fabaceae & 3 & 1,06 \\
\hline Copaifeira langsdorffii & Óleo-de-copaíba & Fabaceae & 1 & 0,35 \\
\hline Thuja orientalis & Tuia & Cupressaceae & 1 & 0,35 \\
\hline Cythalexyllum myrianthum & Tucaneira & Verbenaceae & 1 & 0,35 \\
\hline
\end{tabular}




\begin{tabular}{|c|c|c|c|c|}
\hline NOME CIENTÍFICO & NOME COMUM & FAMÍLIA & NI & FR \% \\
\hline Dypsis lutescens & Areca-bambu & Arecaceae & 2 & 0,71 \\
\hline Elaeis guineensis & Dendê & Arecaceae & 2 & 0,71 \\
\hline Eugenia jambolana & Jambolão & Myrtaceae & 7 & 2,49 \\
\hline Eugenia uniflora & Pitanga & Myrtaceae & 6 & 2,13 \\
\hline Euterpe edulis & Palmeira-juçara & Arecaceae & 1 & 0,35 \\
\hline Fícus guaranitica & Figueira-branca & Moraceae & 3 & 1,06 \\
\hline Fícus elástica & Falsa-seringueira & Moraceae & 4 & 1,42 \\
\hline Fícus insípida & Figueira & Moraceae & 1 & 0,35 \\
\hline Genipa americana & Jenipapo & Rubiaceae & 2 & 0,71 \\
\hline Guarea guidonia & Marinheiro & Meliaceae & 5 & 1,78 \\
\hline Holocalix balansae & Alecrim-de-campinas & Fabaceae & 1 & 0,35 \\
\hline Hymenaea courbaril & Jatobá & Fabaceae & 8 & 2,85 \\
\hline Inga uruguensis & Ingá & Fabaceae & 2 & 0,71 \\
\hline Jacarandá brasiliana & Jacarandá-boca-de-sapo & Bignoniaceae & 4 & 1,42 \\
\hline Swietenia macrophylla & Mogno & Meliaceae & 1 & 0,35 \\
\hline Lecythis pisonis & Sapucaia & Lecythidaceae & 6 & 2,13 \\
\hline Licania tomentosa & Oiti & Chrysobalanaceae & 6 & 2,13 \\
\hline Ligustrum lucidum & Alfeneiro-do-japão & Oleaceae & 3 & 1,06 \\
\hline Livistona chinensis & Palmeira-leque & Arecaceae & 3 & 1,06 \\
\hline Machaerium opacum & Jacarandá-da-bahia & Fabaceae & 2 & 0,71 \\
\hline Machaerium vilhosum & Jacarandá-paulista & Fabaceae & 7 & 2,49 \\
\hline Malpighia glabra & Acerola & Malpighiaceae & 2 & 0,71 \\
\hline Myroxylon peruiferum & Cabreúva & Fabaceae & 7 & 2,49 \\
\hline Morus nigra & Amora & Moraceae & 1 & 0,35 \\
\hline Morus Alba & Amora-branca & Moraceae & 1 & 0,35 \\
\hline Murraya paniculata & Falsa-murta & Rutaceae & 5 & 1,78 \\
\hline Nectandra megapotamica & Canelinha & Lauraceae & 1 & 0,35 \\
\hline Orbignya speciosa & Babaçu & Arecaceae & 3 & 1,06 \\
\hline Oreopanax fulvum & Tamanqueira & Araliaceae & 1 & 0,35 \\
\hline Pachira aquática & Munguba & Bombacaceae & 2 & 0,71 \\
\hline
\end{tabular}




\begin{tabular}{|c|c|c|c|c|}
\hline NOME CIENTÍFICO & NOME COMUM & FAMÍLIA & $\mathbf{N I}$ & FR \% \\
\hline Parapiptadenia pterosperma & Angico-roxo & Fabaceae & 1 & 0,35 \\
\hline Phoenix dactylifera & Tamareira & Arecaceae & 3 & 1,10 \\
\hline Phoenix reclinata & Tamareira-de-moita & Arecaceae & 1 & 0,35 \\
\hline Phoenix roebelenii & Palmeira-phoenix & Arecaceae & 11 & 3,91 \\
\hline Pilocarpus jaborandi & Jaborandi & Rutaceae & 1 & 0,35 \\
\hline Plumeria rubra & Jasmim-manga & Apocynaceae & 3 & 1,06 \\
\hline Psidium guajava & Goiaba & Myrtaceae & 1 & 0,35 \\
\hline Ptychosperma macarthurii & Palmeira-pictiosperma & Arecaceae & 1 & 0,35 \\
\hline Rhapis excelsa & Palmeira-ráfis & Arecaceae & 5 & 1,78 \\
\hline Roystonea oleracea & Palmeira-imperial & Arecaceae & 1 & 0,35 \\
\hline Scheelea macrocarpa & Palmeira-chelia & Arecaceae & 5 & 1,78 \\
\hline Schinus terebinthifolia & Aroeira-branca & Anacardiaceae & 1 & 0,35 \\
\hline Spondias mombin & Cajá-mirim & Anacardiaceae & 3 & 1,06 \\
\hline Sterculia apétala & Chicha & Sterculiaceae & 1 & 0,35 \\
\hline Swietenia macrophylla & Mogno & Meliaceae & 2 & 0,71 \\
\hline Syagrus romanzoffiana & Palmeira-jerivá & Arecaceae & 12 & 4,27 \\
\hline Syagrus oleraceae & Guariroba & Arecaceae & 1 & 0,35 \\
\hline Syzygium jambos & Jambo-comum & Myrtaceae & 1 & 0,35 \\
\hline Syzygium samarangense & Jambo & Myrtaceae & 1 & 0,35 \\
\hline Syzygium malaccense & Jambo-vermelho & Myrtaceae & 5 & 1,78 \\
\hline Tabebuia impetigiosa & Ipê-roxo & Bignoniaceae & 9 & 3,20 \\
\hline Tabebuia róseo-alba & Ipê-branco & Bignoniaceae & 13 & 4,63 \\
\hline Tabebuia chrysotricha & Ipê-amarelo & Bignoniaceae & 4 & 1,42 \\
\hline Tabebuia heptaphylla & Ipê-rosa & Bignoniaceae & 3 & 1,06 \\
\hline Tamarindus indica & Tamarindo & Fabaceae & 3 & 1,10 \\
\hline Terminalia catappa & Sete-copas & Combretaceae & 1 & 0,35 \\
\hline Theobroma cação & Cacau & Malvaceae & 1 & 0,35 \\
\hline Thevetia peruviana & Chapéu-de-napoleão & Apocynaceae & 2 & 0,71 \\
\hline Thrinax parviflora & Palmeira-trinax & Arecaceae & 1 & 0,35 \\
\hline Trichilia hirta & Trequilha & Meliaceae & 1 & 0,35 \\
\hline
\end{tabular}

$\mathrm{NI}$ = número de indivíduos; FR = freqüência relativa (\%) 


\subsection{Levantamento planimétrico}

O mapa planimétrico (Anexo 1) possibilita a visualização de todos os caminhos da Praça Sete de Setembro e a localização das espécies arbóreas.

\subsection{Pesquisa de opinião}

A opinião dos usuários mostrou a satisfação ou insatisfação dos mesmos para com a praça, revelando problemas ocultos, que só o freqüentador local conhece.

Os usuários do sexo feminino representam $61 \%$ do público total, isso provavelmente se deve porque ao redor da praça há muitos prédios em que estas trabalham como empregadas domésticas, babás ou damas de companhia de idosos que por ali moram. Na maioria dos casos, estas mulheres vão à praça descansar, levar crianças para brincar e passear com os idosos. Os resultados para a freqüência de usuários da Praça Sete de Setembro encontram-se na figura 34.

Em Jaboticabal, SP, BORELLA (2009) verificou que a Praça D. Assis, é freqüentada, em sua maioria $(75 \%)$ por usuários masculinos sendo que este alto índice está relacionado com o fato desta praça promover o lazer para a terceira idade, sobretudo, jogos de carteado, bem como, aluguel de fretes, atividades mais comuns para o sexo masculino.

Esta diversidade mostra que as praças devem ser tratadas de forma individual, respeitando as características dos usuários e não como foi feito nas décadas de 50 e 60 onde, por iniciativa dos governos municipais, estaduais e federal, desenvolveu-se um programa de criação de praças para todas as cidades brasileiras, as quais foram desenvolvidas a partir de um projeto padrão (PIVETTA et al., 2008).

De acordo com a pesquisa de opinião verificou-se que $42 \%$ dos freqüentadores da praça possuem idade entre 21 a 40 anos, sendo que, 47\% utilizam a praça para descanso, outros utilizam para passear com as crianças e/ou cachorros, encontrar amigos ou mesmo só de passagem. 
Conforme mostra a figura 35 , o público idoso da praça foi de apenas $14 \%$, eles reclamam que a freqüência de andarilhos e usuários de drogas tem aumentado nos últimos anos, reduzindo o número de idas deste grupo de pessoas à praça.

De forma semelhante e também para praças situadas no centro da cidade, SILVA et al. (2007) observaram maior freqüência de jovens e mínimas de idosos nas praças do Bairro Centro de Teresina, PI. Já SILVA et al. (2008) relatam que as porcentagens de jovens e idosos foram iguais e maiores do que jovens adultos (20 - 40 anos), nas Praças Dr. Augusto Silva e Leonardo Venerando Pereira, Lavras, MG. BORELLA (2009) observou que a grande maioria (69\%) dos freqüentadores da Praça Dom Assis, tem mais de 60 anos, seguidos pela faixa etária de 41 a 60 anos (25\%); a presença de jovens é muito inferior, contando com apenas $6 \%$ sendo, portanto, uma praça com função de lazer para terceira idade.

MELLO \& ROMANINI (2008) na Praça Ernesto Tochetto em Passo Fundo, RS, observaram a freqüência dos usuários bastante igualitária para as diferentes faixas etárias, 38\% dos freqüentadores tinham de 15 a 30 anos, 32\% de 31 a 45 anos e 30\% possuíam em torno de 46 a 70 anos de idade.

A escolaridade dos usuários entrevistados foi de $40 \%$ para o ensino médio, $24 \%$ nível superior e no nível fundamental 13\% (Figura 36).

SILVA et al. (2008) analisando as Praças Dr. Augusto Silva e Leonardo Venerando Pereira, município de Lavras, MG, observaram que a maioria (46\%) dos usuários destas praças apresentavam nível de escolaridade de ensino fundamental, seguido pelo ensino médio (33\%) e superior (21\%).

A maior porcentagem de pessoas com nível de escolaridade entre médio e superior observada neste estudo, pode ser explicado pelo fato da Praça Sete de Setembro estar situada em um município onde há muitas escolas, cursos técnicos e faculdades; deve-se, também, se levar em conta que a grande maioria dos freqüentadores são jovens fazendo com que esse nível de escolaridade aumente; possivelmente, se a praça fosse mais freqüentada pela população idosa, o nível de escolaridade poderia ser mais baixo. 
De acordo com a figura 37, a atividade ocupacional dos entrevistados, são: $63 \%$ são trabalhadores, $12 \%$ são estudantes, $12 \%$ são aposentados, $6 \%$ são donas de casa e 7\% estão desempregados. Provavelmente, a maioria dos usuários são trabalhadores porque grande parte está na idade ativa de trabalho (20 a 41 anos) ou, ainda, porque a praça está localizada na região central de Ribeirão Preto, sendo um local de intenso comércio.

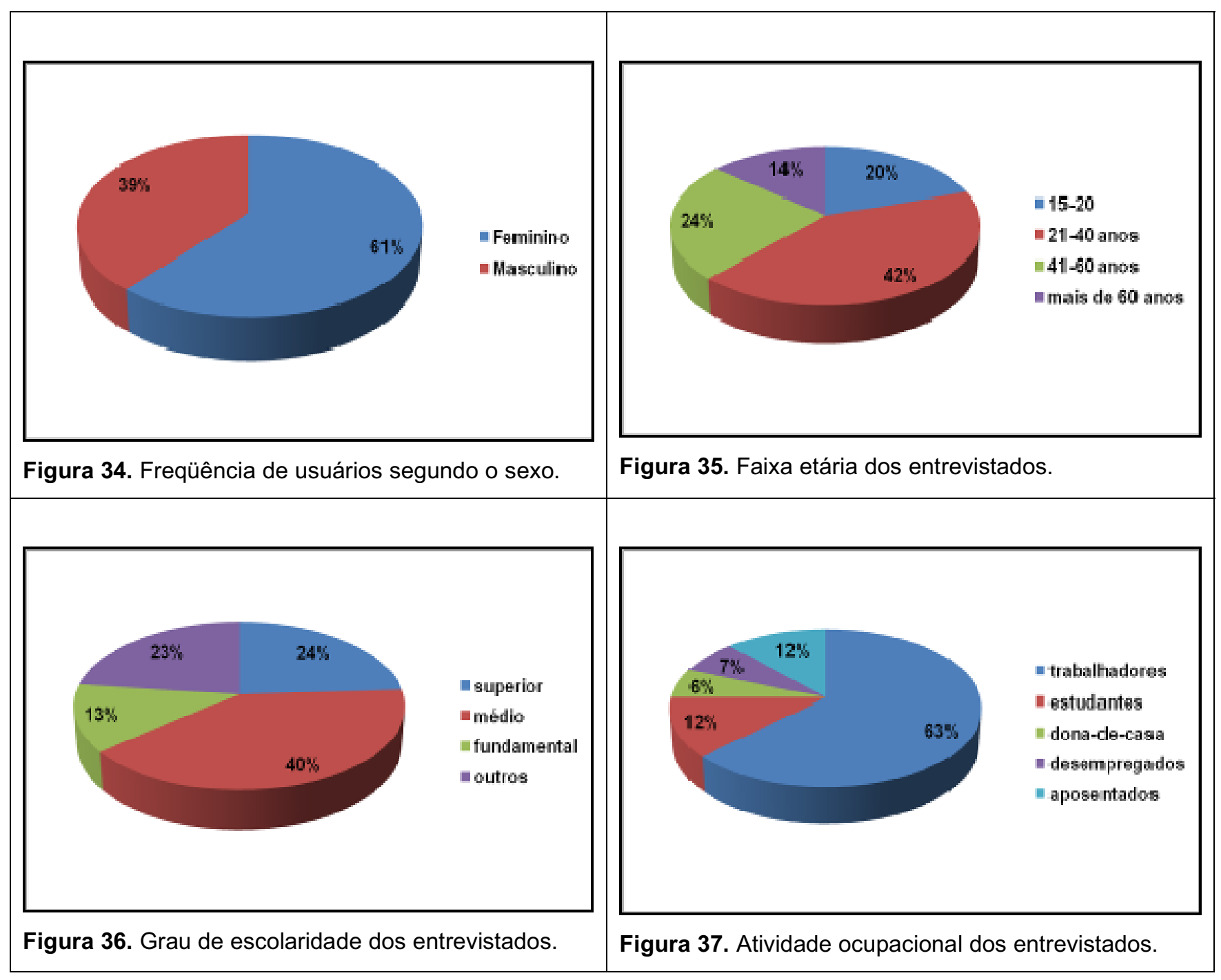


De todos os entrevistados, $85 \%$ dizem ser freqüentadores da praça, alguns vem à praça todos os dias, outros uma vez por semana e outros uma vez por mês.

Quanto à utilização da praça, verifica-se que $24 \%$ dos usuários utilizam a praça para descansar, seguido dos $15 \%$ para levar criança para passear. Neste quesito de utilização do espaço, obtiveram-se as mais diversas respostas, como caminhar, levar o cachorro para passear, passar o horário de almoço na praça, utilização da praça apenas como passagem, tomar sorvete (em frente à praça há uma sorveteria bastante tradicional da cidade, atraindo muitas pessoas), namorar, encontrar amigos, etc. Conforme ilustra a figura (Figura 38).

O estudo dos espaços livres e de uso público realizado na cidade de Ribeirão Preto por GUZZO (1999) relata que a Praça Aureliano de Gusmão é utilizada para passeio com crianças e cachorros, skate, patins, bicicleta, caminhada, namoro, descanso e contemplação, conversas e etc.

A maioria dos usuários (24\%) fica por volta de 1 hora na praça. Existem usuários que freqüentam a praça desde 15, 30 e 40 minutos e também aqueles que ficam em torno de 2, 3 a 4 horas por visita.

Quando perguntado aos entrevistados o que eles mais gostam da praça, 33\% responderam serem as árvores, seguido de 19\% que disseram ser a tranqüilidade do local e os demais responderam que gostam do verde, do ar puro, da limpeza e da sombra (Figura 39).

GUZZO (2009) verificou em seu estudo que os usuários são atraídos pela tranqüilidade e beleza, pelas árvores, segurança, o canto dos pássaros, limpeza e etc.

Quanto ao que menos gostam, 44\% dos entrevistados responderam não gostar da presença de mendigos, usuários de drogas e os "guardadores de carro".

Cerca de $10 \%$ dos entrevistados preferiram não opinar e, 17\% não têm nada a reclamar da Praça Sete de Setembro.

Às quartas-feiras durante a pesquisa de opinião, verificou-se a ocorrência de encontros de casais homossexuais, na maioria do sexo feminino, causando certo receio dos demais usuários que freqüentam a praça, pois segundo os próprios entrevistados, se sentem desconfortáveis com as atitudes expostas por esse grupo de pessoas. 
Quando os usuários foram questionados sobre o que é necessário melhorar na praça, $37 \%$ responderam ser a segurança, sugerindo mais policiamento e solicitando guarda municipal 24 horas na praça. Os usuários satisfeitos com a praça e que alegam não haver melhorias para serem feitas somam 15\% dos entrevistados. Os demais sugeriram melhoria na limpeza, instalação de bebedouros e torneiras para higiene das mãos, construção de banheiro, parquinho para as crianças, entre outros.

Destacando como maior problema relatado pelos entrevistados é a presença de andarilhos, usuários de drogas e pessoas que ficam pedindo esmolas em troca de cuidar dos carros estacionados ao redor da praça, estes são vistos como ameaça a segurança da população que freqüenta o local. O pedido de segurança é unânime pelos usuários. Embora seja feita a ronda por parte da Policia Militar e Guarda Municipal, os mesmos não permanecem no local por muito tempo o que traz desconforto a população local. Também não foi relatado casos de ocorrência policial por nenhum usuário.

GUZZO (1999) estudou os espaços livres de uso público da cidade de Ribeirão Preto e relatou a presença de um abrigo da guarda municipal na Praça Sete de Setembro. Atualmente este abrigo não existe mais.

Quando questionados sobre as outras praças de Ribeirão Preto, alguns responderam que as consideram abandonadas tanto na parte de cuidados e manutenção (35\%), como na segurança (25\%), já outros consideram as praças "boas" (19\%) e 13\% não opinaram, o restante (8\%) não deram respostas significativas. Algumas pessoas não quiseram opinar, pois alegam freqüentar apenas a Praça Sete de Setembro.

A maioria dos entrevistados (62\%) concorda que a mudança da infra-estrutura da praça ao longo dos anos trouxe melhorias para a praça, ressaltando a limpeza e o policiamento. Em contrapartida, $7 \%$ disseram que a praça piorou em relação ao público que a freqüenta e a falta de limpeza. Parte significante da entrevista (31\%) relata não ter notado melhoria ou piora na praça (Figura 40).

Quanto ao quesito limpeza na praça, verifica-se uma controvérsia, pois ocorre devido ao horário que o usuário vai à praça. No período da manhã, a praça é varrida e as lixeiras são esvaziadas, a limpeza permanece até por volta das 14 horas. Após esse 
horário, verifica-se a péssima utilização do bem público pelos próprios usuários, que descartam papéis, copos, embalagens e outros objetos.

Dentre os entrevistados, $74 \%$ conhecem o nome atual da praça, ou seja, Sete de Setembro, visto que no passado chamava-se "Aureliano de Gusmão", o que provocou confusão aos entrevistados; algumas pessoas ainda acreditavam que o nome da praça permanecia o antigo (Figura 41).

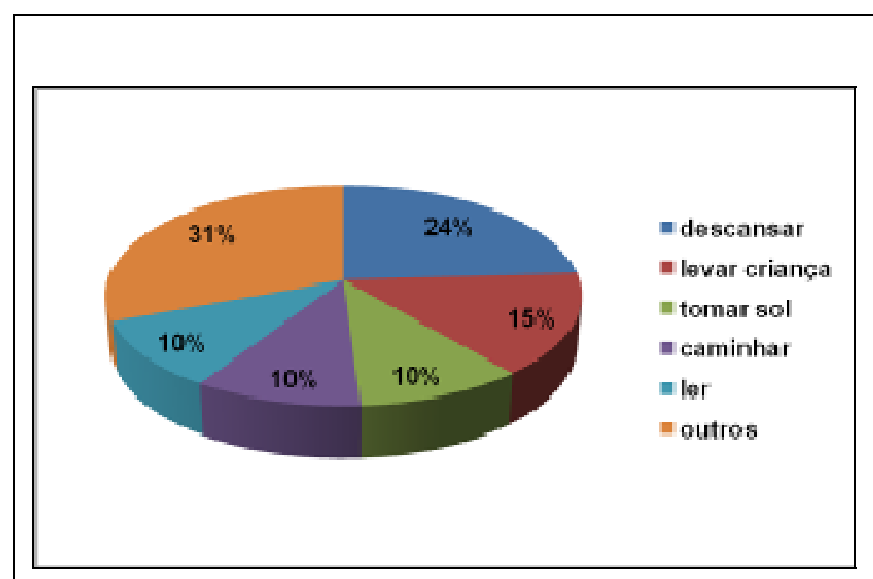

Figura 38. Motivos de utilização da praça segundo os entrevistados.

Figura 39. O que os entrevistados mais gostam na praça.

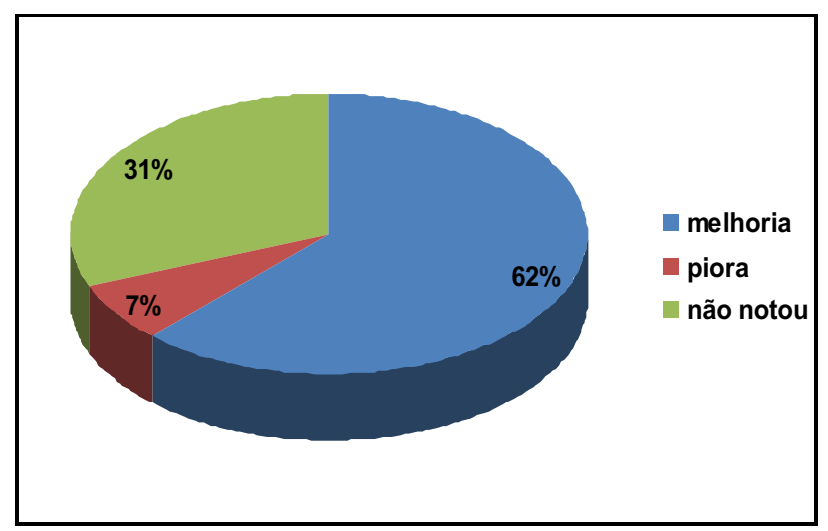

Figura 40. Mudança da infra-estrutura da praça ao longo dos anos.

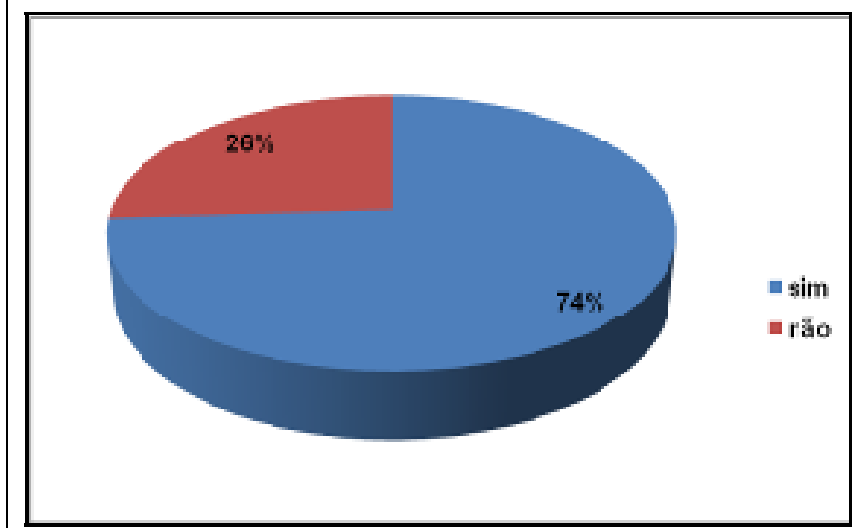

Figura 41. Conhecimento do nome da Praça Sete de Setembro pelos entrevistados. 
MELO e ROMANINI (2008), analisando a Praça Ernesto Tochetto, Passo Fundo, RS, observaram índices semelhantes de conhecimento do nome da praça, sendo da ordem de $23 \%$ para os usuários cuja faixa etária era de 46 a 70 anos, 35\% para 31 a 45 anos e somente entre os mais jovens (15 a 30 anos) verificou-se grande porcentagem (42\%) de usuários que não sabiam o nome da praça.

Ao perguntar para as pessoas sobre a história da Praça Sete de Setembro, apenas 3\% relatou ter ouvido que antes havia um cemitério instalado no local.

Semelhantemente, BORELLA (2009) também verificou que a maioria (83\%) dos usuários tinha conhecimento do nome da praça (D. Assis, Jaboticabal, SP), porém, somente $3 \%$ sabia sobre a história da mesma. No entanto, no trabalho de BORELLA (2009), a maioria dos usuários tinha mais que 60 anos, sendo mais comum conhecer aspectos ligados a historia do município.

\section{CONCLUSÕES}

Com o levantamento histórico da Praça Sete de Setembro, conclui-se que a mesma desde o início do século passado já tinha grande importância para os ribeirãopretanos. Atualmente, verifica-se uma intensa urbanização ao seu redor, e o local permanece agradável e atrativo à população com suas árvores majestosas.

Atualmente a praça promove aos seus usuários lazer, convívio social e entretenimento com os eventos sociais e culturais que ali ocorrem, reunindo pessoas dos mais diversos grupos que ali freqüentam, desde crianças a idosos, com diferentes classes sociais.

Com a análise quali-quantitativa dos elementos arquitetônicos, conclui-se que o local tem a função de promover lazer a diferentes grupos de pessoas, preferencialmente do sexo feminino, de 21 a 40 anos, que as usam para descanso e passeio com as crianças. 
A praça contribui para a qualidade de vida e conforto térmico da população, graças à diversidade das espécies arbóreas (86 espécies num total de 281 exemplares).

\section{REFERÊNCIAS BIBLIOGRÁFICAS}

ABBUD, B. Criando paisagens - Guia de trabalho em arquitetura. 3. ed. São Paulo: Senac, 2006. p. 1-6.

BARTENSTEIN, F. The future of urban forestry. Journal of Arboriculture, Savoy, v. 7, n. 10 , p. 261-267, 1981.

BERNATZKY, A. The contribution of trees and Green spaces to a town climate. In: Energy and buildings, Frankfurt, v. 5, n.1, p. 1-10, 1982.

BOTTURA, I. A. F.; BONFÁ, T. A. F. Ribeirão Arte. Ribeirão Preto: Publicação Ribeirão Arte, s/d.

BORELLA, H. D. Importância histórica - cultural e situação atual da Praça Dom Assis, Jaboticabal, São Paulo. Monografia (Trabalho de Graduação em Agronomia) Faculdade de Ciências Agrárias e Veterinárias, Universidade Estadual Paulista, Jaboticabal, 2009.

CARVALHO, L. M. Áreas verdes da cidade de Lavras/ MG: caracterização, usos e necessidades. Dissertação (Mestrado em Agronomia) - Universidade Federal de Lavras, Lavras, 2001.

CIONE, R. História de Ribeirão Preto. Ribeirão Preto: Legis Summa, 1987, v. 1.

CIONE, R. História de Ribeirão Preto. Ribeirão Preto: Legis Summa, 1992, v. 2. 
CLIFFORD, D. Los jardines: historia, trazado y arte. Madrid: Instituto de Estudios de la Administración, 1970. 245p.

CRONQUIST, A. J. The evolution and classification of flowering plants. 2. ed. New York: Botanical Garden, 1988.

DE ANGELIS, B. L. D. A praça no contexto das cidades - o caso de Maringá, PR. 2000. 366f. Tese (Doutorado em Geografia Humana) - Faculdade de Filosofia, Letras e Ciências Humanas, Universidade de São Paulo, 2000.

DE ANGELIS, B. L. D.; ANGELIS NETO, G. de. Os elementos de desenho das praças de Maringá-PR. Acta Scientiarum, Maringá, v. 22, n. 5, p.1445-1454, 2000.

DE ANGELIS, B. L. D.; CASTRO, R. M.; DE ANGELIS NETO, G. Metodologia para levantamento, cadastramento, diagnóstico e avaliação de praças no Brasil. Engenharia Civil, Guimarães, Portugal, n. 20, p. 57-70, 2004.

DE ANGELIS, B. L. D.; DE ANGELIS NETO, G.; BARROS, G. D. A.; BARROS, R. D. A. Praças: história, usos e funções. Maringá: EDUEM, 2005.

DEMATTÊ, M. E. S. P. Princípios de paisagismo. 2. ed. Jaboticabal: FUNEP, 1999, p. 101.

FARIA, R. T. de. Paisagismo: harmonia, ciência e arte. Londrina, PR: Mecenas, 2005, p. 132.

GOMES, M. A. S. As praças de Ribeirão Preto-SP: uma contribuição geográfica ao planejamento e à gestão dos espaços públicos. 2005. 202f. Dissertação (Mestrado 
em Geografia) - Instituto de Geografia. Universidade Federal de Uberlândia, Uberlândia, 2005.

GREY, G. W.; DENEKE, F. J. Urban forestry. New York: John Wiley, 1978. 279p.

GRIMAL, P. L'art dês jardins. Paris: Universitaires de France, 1974, p. 127.

GUZZO, P. Estudos dos espaços livres de uso público da cidade de Ribeirão Preto/SP, com detalhamento da cobertura vegetal e áreas verdes públicas de dois setores urbanos. 1999. 126f. Dissertação (Mestrado em Geografia) - Instituto de Geociências e Ciências Exatas, Universidade Estadual Paulista, Rio Claro, 1999.

GUZZO, P. Arborização urbana. 1991. Disponível em: <http://educar.sc.usp.br/biologia/prociencias/arboriz.html>. Acesso em: 20 out. 2009a.

GUZZO, P. Áreas verdes urbanas. 2002. Disponível em: $<$ http://educar.sc.usp.br/biologia/prociencias/areasverdes.html>. Acesso em: 13 out. 2009b.

Histórico de Ribeirão Preto, uma região em pleno desenvolvimento. Disponível em: <http://www.ribeiraopreto.sp.gov.br/crp/i71regiao.htm>. Acesso em: 02 jul. 2009.

IBGE Instituto Brasileiro de Geografia e Estatística. 2009. Disponível em: <http://www.ibge.gov.br/cidadesat/topwindow.htm?1>. Acesso em: 09 fev. 2010.

JOHNSTON, M. Community forestry: a sociological approach to urban forestry. Arboricultural Journal, Oxon, v. 9, n. 2, p. 121-126, 1985. 
LEFEVRE, H. N. Espaços livres urbanos. Revista Engenharia, v. 10, n. 116, p. 407, 1952. Disponível em: <http://www.tdx.cbuc.es/TESIS_UPC/AVAILABLE/TDX1107108100349/21Flo21de21.pdf>. Acesso em: 30 out. 2009.

LIMA, A. M. L. P.; CAVALHEIRO, F.; NUCCI, J. C.; SOUSA, M. A. L. B., FIALHO, N. O.; DEL PICHIA, P. C. D. Problemas de utilização na conceituação de termos como espaços livres, áreas verdes e correlatas. In: CONGRESSO BRASILEIRO DE ARBORIZAÇÃO URBANA, 1994, São Luís. Anais... São Luís: Sociedade Brasileira de Arborização Urbana. p. 539-553.

LOMBARDO, M. A. Vegetação e clima. In: ENCONTRO NACIONAL SOBRE VEGETAÇÃO URBANA, 3, 1990, Curitiba/PR. Anais... Curitiba: Pesquisas Florestais do Paraná, 1990. p. 1-13.

LORENZI, H. Árvores brasileiras. São Paulo: Plantarum, 1992, v. 1.

LORENZI. H. Árvores brasileiras. 2. ed. São Paulo: Plantarum, 1998, v. 2.

MACEDO, S. S.; SAKATA, F. G. Parques urbanos no Brasil. 2. ed. São Paulo: Universidade de São Paulo, 2003. 207p.

MACEDO, S. S. Espaços livres. In: Paisagem e ambientes ensaios. FAUSP, 1993. Disponível em: <http: //www.adufpb.org.br/publica/conceitos/05/art_04.pdf>. Acesso em: 25 Ago. 2009.

MARX, M. Cidade brasileira. São Paulo: Melhoramentos/Editora da Universidade de São Paulo, 1980. 
MELLO, E. F. R. Q.; ROMANINI, A. Praça Ernesto Tochetto: importância da sua preservação histórica e aspectos de sua arborização. Revista da Sociedade Brasileira de Arborização Urbana, Piracicaba, v. 3, n. 1, p. 54-52, 2008.

MILANO, M. S.; DALCIN, E. C. Arborização de vias públicas. Rio de Janeiro, RJ: Light, 2000. 226 p.

PAIVA, H. N de; GONÇALVES, W. Florestas urbanas: planejamento para melhoria da qualidade de vida. Viçosa, 2002. v. 2, 180 p.

PAIVA, P. D. O.; ALVES, S. F. N. S. C. Paisagismo I: histórico, definições e caracterizações. Lavras: UFLA/FAEPE, 2002. 139 p. (Textos Acadêmicos).

PEGOLO, L. C. N. C.; DEMATTÊ, M. E. S. P. Estudo sobre as principais praças de Jaboticabal e Taquaritinga (SP). Holos Environment, Rio Claro, v. 2, n. 1, 2002. (CD ROM).

PIVETTA, K. F. L., PAIVA, P. D. O., NERI, F. C. S. Paisagismo em grandes espaços. In: PAIVA, P. D. O. Paisagismo: conceitos e aplicações. Lavras: UFLA, 2008. p. 179-211.

QUEIROGA, E. F. Entre a megalópole e a praça: notas dialéticas sobre paisagens urbanas contemporâneas e possibilidades projetuais do espaço público. In: Paisagens em debate, São Paulo, n.n. especial, p.1-10, 2004.

RIBEIRÃO PRETO - CÂMARA MUNICIPAL. Actas das sessões, 1811-1930.

RIBEIRÃO PRETO. Disponível em: <http://www.wikipedia.org/wiki/Ribeirão Preto>. Acesso em: 02 jul. 2009.

RIGOTTI, G. Urbanística - la técnica. 2. ed. Torino: Editrice Torinese, 1956. 
ROBBA, F.; MACEDO, S. S. Praças brasileiras: public squares in Brazil. São Paulo: Edusp, 2002. p. 17.

ROBBA, F.; MACEDO, S. S. Praças brasileiras. 2. ed. São Paulo: Universidade de São Paulo, 2003. 311 p. (Coleção Quapá).

ROBERTS, B. R. The physiology of trees in and near human settlements. In: ANDRESEN, J. W. (Ed.). Trees and forests for human settlements. Toronto: Centre for Urban Forestry Studies, p. 293 - 308, 1980.

RODERJAN, C. V.; BARDDAL, M. L. Arborização das ruas de Curitiba - PR; guia prático para identificação das espécies. Curitiba: FUPEF, 1998. 14p.

SCHUBERT, T. H. Trees for urban use in Puerto Rico and Virgin Island. New Orleans: U. S. Department of Agriculture, Forest Service, 1979. 91 p. (General Technical Report SO - 27).

SEGAWA, H. Ao amor do público: jardins no Brasil. São Paulo: Studio Nobel/ FAPESP, 1996. 31p.

SILVA, I. M.; RAMOS, L. M. P.; BRITO, J. S. Análise das funções das praças do bairro centro de Teresina - PI. In: CONGRESSO DE PESQUISA E INOVAÇÃO DA REDE NORTE NORDESTE DE EDUCAÇÃO TECNOLÓGICA, 2, 2007, João Pessoa. Anais... João Pessoa, 2007.

SILVA, A. T.; TAVARES, T. S.; PAIVA, P. D. O.; NOGUEIRA, D. A. As Praças Dr. Augusto Silva e Leonardo Venerando Pereira, Lavras-MG, segundo a visão dos seus freqüentadores. Ciência e Agrotecnologia, Lavras, v. 32, n. 6, p. 1701-1707, 2008. 
SOUZA, B. A. A. Análise da utilização pelos usuários de duas praças em BetimMG. 2005. 53f. (Trabalho de Graduação em Arquitetura e Urbanismo) - Universidade Federal de Lavras, Lavras, MG, 2005.

TEIXEIRA, N. C. Versos à Ribeirão Preto: crônicas e poesias. 1970. 220 p.

VILAS BOAS, N. B. O passeio público do Rio de Janeiro: análise histórica da percepção do espaço. 1999. 200f. Dissertação (Mestrado em Arquitetura) Universidade Federal do Rio de Janeiro, Rio de Janeiro, 1999. 
ANEXOS 


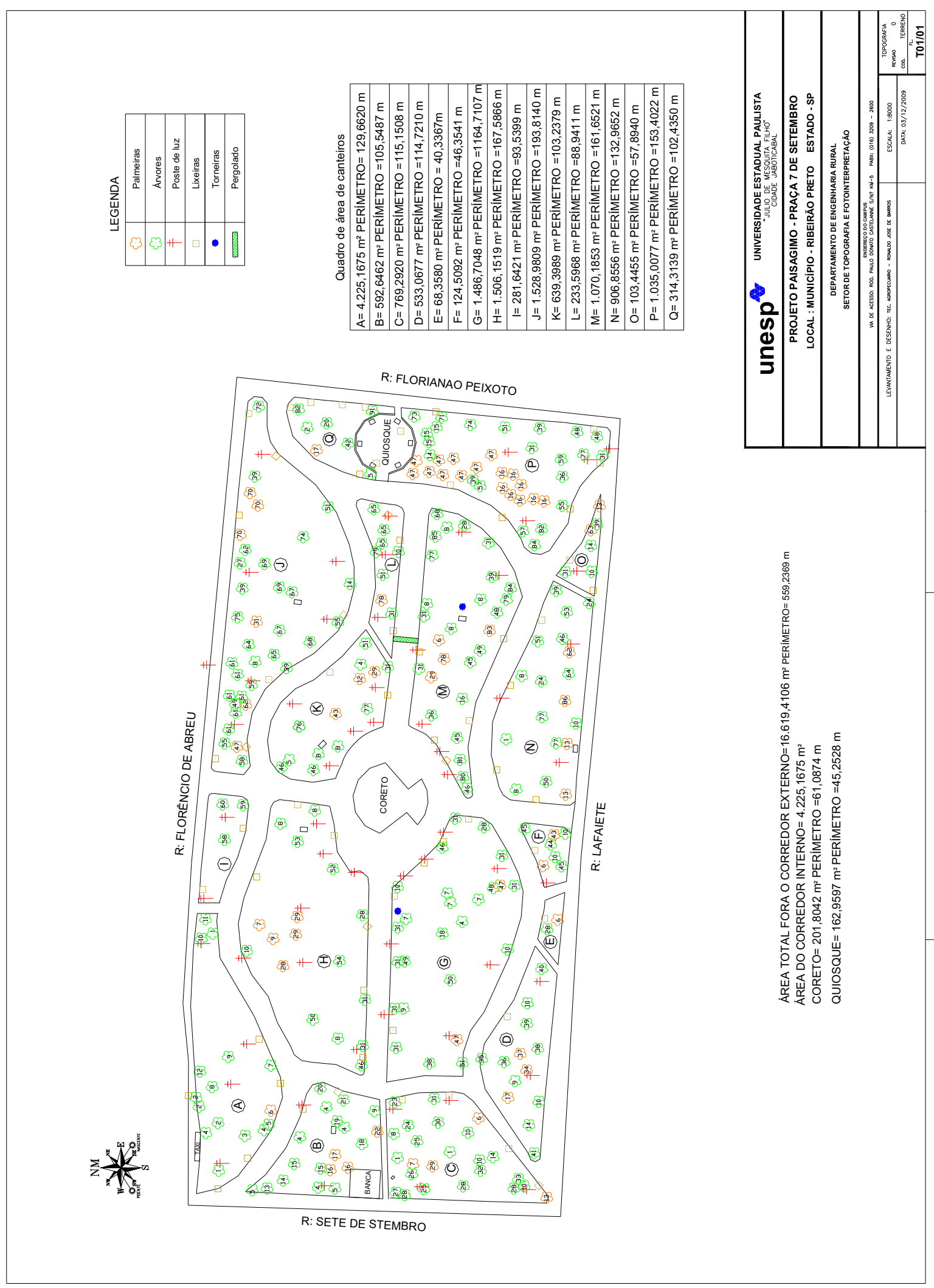


Anexo 2. Identificação das espécies arbóreas alocadas no mapa planimétrico.

\begin{tabular}{|c|c|c|c|}
\hline Número & Nome comum & Número & Nome comum \\
\hline 1 & Sapucaia & 44 & Jequitibá-rosa \\
\hline 2 & Falsa-seringueira & 45 & Jacarandá-boca-de-sapo \\
\hline 3 & Canelinha & 46 & Oiti \\
\hline 4 & Cabreúva & 47 & Palmeira-jerivá \\
\hline 5 & Pitanga & 48 & Ipê-amarelo \\
\hline 6 & Palmeira-chélia & 49 & Tamarindo \\
\hline 7 & Jacarandá-paulista & 50 & Pau-ferro \\
\hline 8 & Peroba-rosa & 51 & Jambo-vermelho \\
\hline 9 & Marinheiro & 52 & Cacau \\
\hline 10 & Ipê-branco & 53 & Munguba \\
\hline 11 & Goiaba & 54 & Tucaneira \\
\hline 12 & Palmeira-leque & 55 & Ipê-rosa \\
\hline 13 & Pupunha & 56 & Chicha \\
\hline 14 & Jambolão & 57 & Alfeneiro-do-japão \\
\hline 15 & Falsa-murta & 58 & Jequitibá-branco \\
\hline 16 & Palmeira-phoenix & 59 & Chuva-de-ouro \\
\hline 17 & Babaçu & 60 & Peroba \\
\hline 18 & Jenipapo & 61 & Manacá \\
\hline 19 & Cássia-excelsa & 62 & Tamareira \\
\hline 20 & Jaca & 63 & Palmeira-juçara \\
\hline 21 & Cedro-rosa & 64 & Aroeira-branca \\
\hline 22 & Guariroba & 65 & Jasmim-manga \\
\hline 23 & Sete-copas & 66 & Jequitibá-vermelho \\
\hline 24 & Figueira-branca & 67 & Jacarandá-da-bahia \\
\hline 25 & Araribá & 68 & Ingá \\
\hline 26 & Trequilha & 69 & Caju \\
\hline 27 & Acerola & 70 & Palmeira-real-da-austrália \\
\hline 28 & Ipê-roxo & 71 & Amora \\
\hline 29 & Palmeira-ráfis & 72 & Carambola \\
\hline 30 & Óleo-de-copaíba & 73 & Urucum \\
\hline 31 & Sibipiruna & 74 & Cajá-mirim \\
\hline 32 & Tuia & 75 & Jambo-comum \\
\hline 33 & Tamanqueira & 76 & Alecrim-de-campinas \\
\hline 34 & Palmeira-pictiosperma & 77 & Pau-brasil \\
\hline 35 & Figueira & 78 & Dendê \\
\hline 36 & Farinha-seca & 79 & Graviola \\
\hline 37 & Palmeira-imperial & 80 & Angico-roxo \\
\hline 38 & Mogno & 81 & Jaborandi \\
\hline 39 & Jatobá & 82 & Paineira-rosa \\
\hline 40 & Jambo & 83 & Tamareira-de-moita \\
\hline 41 & Mogno & 84 & Chapéu-de-napoleão \\
\hline 42 & Amora-branca & 85 & Peroba-poca \\
\hline 43 & Areca-bambú & 86 & Palmeira-trinax \\
\hline
\end{tabular}

